\title{
Munzur ve Pülümür Vadilerinde (Tunceli) Bulunan Sıcak ve Mineralli Kaynakların Bölgenin Yapısal Unsurları ile İlişsisi ve Hidrojeokimyasal Özellikleri
}

\author{
Ayten Öztüfekçi Önal ${ }^{1}$, Taylan Sançar²* \\ ${ }^{I}$ Munzur Üniversitesi, Mühendislik Fakültesi, Jeoloji Mühendisliği Bölümü, Tunceli, Türkiye \\ ${ }^{2}$ Munzur Üniversitesi, Edebiyat Fakültesi, Coğrafya Bölümü, Tunceli, Türkiye

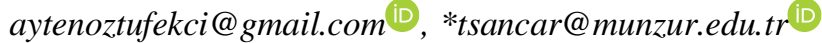 \\ Makale gönderme tarihi: 11.10.2020, Makale kabul tarihi: 19.01.2021
}

\begin{abstract}
$\ddot{O ̈ z}$
Tunceli'deki en büyük akaçlama alanlarına sahip olan K-G akışlı Munzur ve Pülümür Nehirleri Tunceli Merkez'de birleşerek güneye doğru tek nehir olarak devam eder. Güneydeki alanda Dinar ve Rabat gibi daha küçük akaçlama alanları yer alır. Bu çalışmada sözü edilen akaçlama alanları içerisinde yer alan sıcak ve mineralli kaynakların hidrojeokimyasal özellikleri ve bu kaynakların bölgedeki faylar ile ilişkisi araştırılmıştır. Sıcak ve mineralli kaynakların yüzeye ulaşmasını kontrol eden en önemli yapısal unsur sağ yanal doğrultu-atımlı Nazımiye Fay Zonu'nun birincil ve ikincil deformasyon yapılarıdır. Permo-Karbonifer yaşılı geçirimsiz şistler hidrojeolojik olarak bölgedeki temel kayaları oluştururlar. Munzur ve Pülümür nehirlerinin akaçlama alanlarında yer alan sıcak ve mineralli suların hazne kayası Permiyen yaşlı mermer ve kristalize kireçtaşlarıdır. Bu hazne kayaların beslenme bölgesinde yayılım sunan EosenMiyosen yaşlı yarı geçirimli fliş ve geçirimli kireçtaşlarının varlığı, sistemin açık olduğuna işaret etmektedir. Sistemdeki sıcak ve mineralli suların $\mathrm{pH}$ ve elektriksel iletkenlikleri sırasıyla 5.96-6.80 ve 2231-2930 $\mu$ S/cm arasındadır. Yüzeye çıkış sıcaklıkları ise $35-20^{\circ} \mathrm{C}$ arasında değişmektedir. Toplam çözünmüş katı madde miktarları 1300-1600 mg/L arasındadır. Sularda en fazla bulunan katyon Ca+2, anyon ise HCO3-'dır. Sicak ve mineralli suların $\mathrm{Na}-\mathrm{K}-\mathrm{Mg}$ jeotermometre sonuçları, su-kayaç ilişkisinin dengede olmadığı ham sulara karşılık gelmektedir. Soğuk suların $\mathrm{pH}$ ve elektriksel iletkenlik değerleri ise sırasıyla 6.66-7.28 ve 471-891 $\mu \mathrm{S} / \mathrm{cm}$ arasında değişmektedir. İncelenen tüm sular $\mathrm{Ca}-\mathrm{Mg}-\mathrm{HCO} 3$ tipindedir.
\end{abstract}

Anahtar kelimeler: Jeoloji, yapısal ilişki, hidrojeokimya, sıcak ve mineralli su, Tunceli

\section{The Relationship of the Hot and Mineral Springs in Munzur and Pülümür Valleys (Tunceli) with the Tectonic Structures of the Region and their Hydrogeochemical Properties}

\begin{abstract}
The N-S flowing Munzur and Pülümür Rivers, which have the largest drainage areas in Tunceli Province, merge in the city center, and continue as a single river towards the south. In the southern area, there are smaller drainage areas such as Dinar and Rabat. In this study, the hydrogeochemical properties of the hot and mineral springs located in the mentioned drainage areas and the relationship of these springs with the faults in the region were investigated. The most important structural element controlling the reaching of hot and mineral springs to the surface is the primary and secondary deformation structures of the right lateral strike-slip Nazımiye Fault Zone. PermoCarboniferous aged impermeable schists form the basement rocks in the area hydrogeologically. Permian aged marble and crystallized limestones are the reservoir rocks of the hot and mineral waters which are outcropped in the drainage areas of Munzur and Pülümür Rivers. The presence of Eocene-Miocene aged semi-permeable flysch and permeable limestones cover rocks in this recharge area of the reservoir rocks indicates that the system is open. The $\mathrm{pH}$ and electrical conductivity of the hot and mineral waters in the system change between 5.96-6.80 and 2231-2930 $\mu \mathrm{S} / \mathrm{cm}$, respectively. Temperature of these waters varies between 35 to $20^{\circ} \mathrm{C}$ when they reach up to the surface. The total amount of dissolved solids ranges from 1300 to $1600 \mathrm{mg} / \mathrm{L}$. The most abundant cation present in the waters is $\mathrm{Ca}+2$; the most abundant anion is $\mathrm{HCO} 3-$. The $\mathrm{Na}-\mathrm{K}-\mathrm{Mg}$ geothermometer results of the hot and mineral waters correspond to the immature waters where the water-rock relationship is not an equilibrium. The $\mathrm{pH}$ and electrical conductivity of the
\end{abstract}


cold waters are between 6.66 to 7.28 and 471 to $891 \mu \mathrm{S} / \mathrm{cm}$, respectively. All waters examined here are of the Ca-Mg HCO3 type.

Keywords: Geology, structural relationship, hydrogeochemistry, hot and mineral water, Tunceli

\section{GİRIS}

Yaklaşık 13 milyon y1l önce Neotetis okyanusunun güney kolunun kapanması Türkiye için neotektonik dönemin başlangıcı sayılır (Şengör, 1980; Şengör ve Yılmaz, 1981; Şengör ve ark., 1985). Türkiye'nin de içinde yer aldığı Doğu Akadeniz'in karmaşık tektonik yapısı genel olarak Avrasya, Afrika, Arabistan Levhaları ve göreceli olarak küçük Anadolu Bloğu'nun birbirleri ile olan etkileşimi sonucu şekillenir. Doğu Akdeniz'in tektonik deformasyonunu doğuda Zagros dalmabatma/çarpışma kuşağı, batıda ise Helenik Yayı ve onun geri çekilmesi kontrol eder (Şekil 1) (McKenzie, 1972; Le Pichon ve Kreemer, 2010).

$\mathrm{Bu}$ deformasyon zonu içerisinde Anadolu Bloku'nun batıya doğru olan hareketinin nedenine dair farklı görüşler ileri sürülmüştür (McKenzie, 1972; Şengör ve ark., 1985; Chorowicz ve ark., 1999; Reilinger ve ark., 2006; Le Pichon ve Kreemer, 2010; Özeren ve Holt, 2010; Faccenna ve ark., 2013). Bu görüşlerden bir ya da birkaçının etkisi ile batıya doğru hareket eden Anadolu Bloğu Avrasya Levhası'na göre, Euler kutbu Nil deltasında olmak üzere (Reilinger ve ark., 1997; McClusky ve ark., 2000) saatin tersi yönünde rotasyona uğrar (Reilinger ve ark., 2006). Oluşan rotasyon hareketi ile birlikte batıya doğru y1llık $21 \mathrm{~mm} / \mathrm{y} 1 \mathrm{l} \mathrm{h}$ hz (Reilinger vd., 2006) ile hareket eden Anadolu Bloğu Türkiye'de (a) Doğu Anadolu Sıkışma
Bölgesi, (b) Kuzey Anadolu Bölgesi, (c) Orta Anadolu "Ova" Bölgesi, (d) Batı Anadolu Gerilme Bölgesi olarak bilinen dört Neotektonik bölge oluşumuna neden olur (Şekil 1) (Şengör, 1980).

Bat1 Anadolu Gerilme Bölgesi jeotermal enerji potansiyeli açısından enerji üretimine imkan veren yüksek entalpili kaynaklar ile karakterize olurken (Mutlu, 1998; Akan, 2002; Akkus ve ark., 2005; Köse, 2005, 2007; Magri ve ark., 2010; Bülbül ve ark., 2011; Cakin ve ark., 2012; Alacal1, 2013) Orta Anadolu "Ova” Bölgesi'nin doğu kesimleri daha çok kaplıca, seracılık vb. amaçlı kullanılan düşük entalpili jeotermal kaynaklar ile karakterize olur (Öztekin Okan, 2004; Firat Ersoy ve Çalik Sönmez, 2014; Akkuş, 2016; Alacali, 2018).

Yüksek entalpili jeotermal sahaların bulunduğu Batı Anadolu Gerilme Bölgesi, dünyanın en aktif gerilme bölgelerinden biridir ve bölgedeki jeotermal sahalar buradaki rejim sonucunda oluşmuş horstgraben yapıları içerisinde görülür. Daha düşük entalpiye sahip jeotermal sahaların bulunduğu Orta Anadolu "Ova" Bölgesi'nin doğu kesimlerindeki jeotermal sahalar ise ağırlıklı olarak doğrultu-atımlı faylar üzerinde yer alır (Öztekin Okan, 2004; Akkuş, 2016; Alacali, 2018; Öztüfekçi Önal ve Akkuş, 2019). 


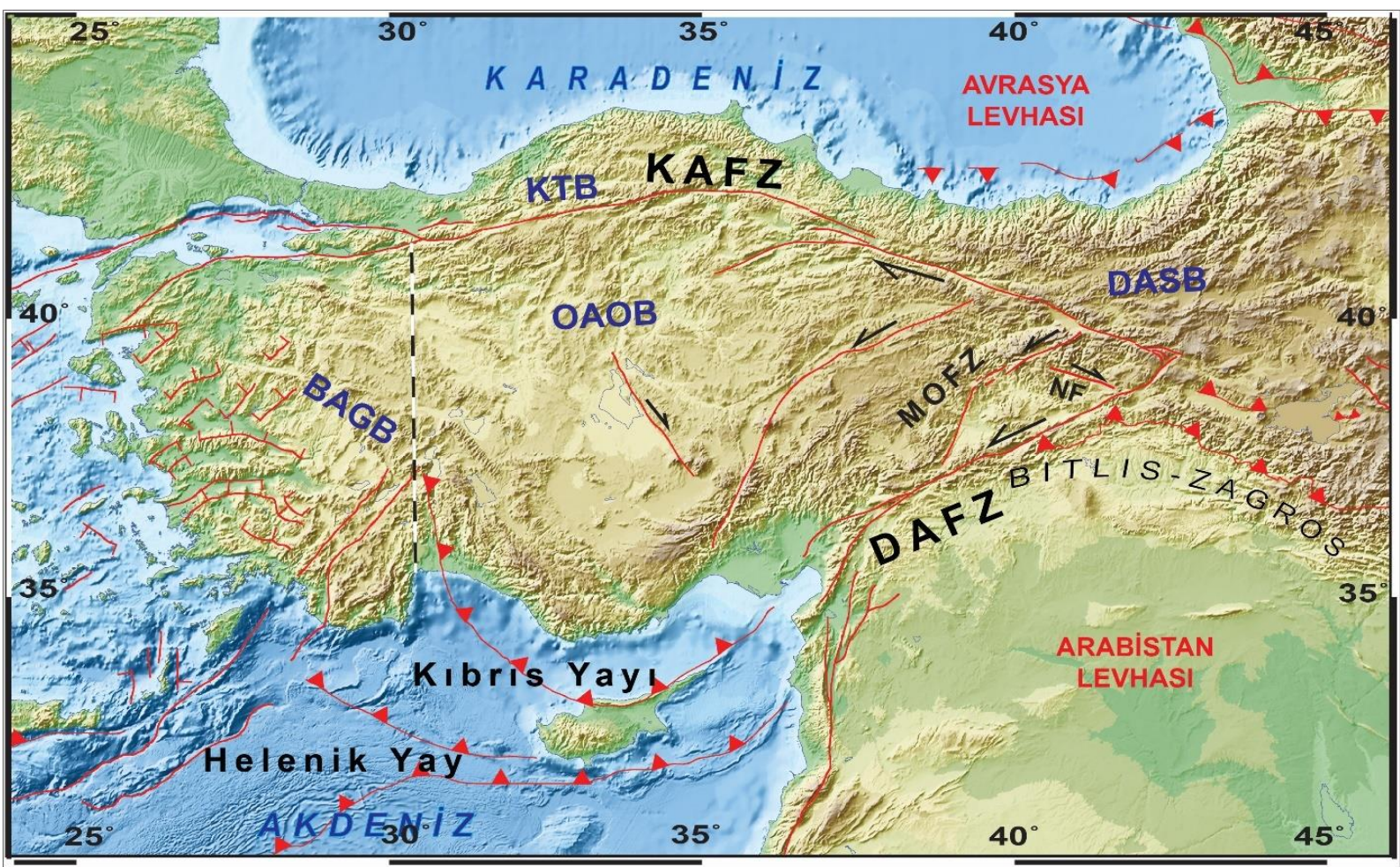

Şekil 1. Türkiye ve civarındaki ana tektonik yapıların dağılımı (Şengör ve ark., 1985; Philip ve ark., 1989; Şaroğlu ve ark., 1992; Le Pichon ve ark., 1995; Koçyiğit ve Beyhan, 1998; Nyst ve Thatcher, 2004; Şengör ve ark., 2005; Akyuz ve ark., 2006; Avagyan ve ark., 2010; Searle ve ark., 2010; Shaw ve Jackson, 2010; Duman ve Emre, 2013; Hall ve ark., 2014; Şengör ve ark., 2014) KAFZ: Kuzey Anadolu Fay Zonu, DAFZ: Doğu Anadolu Fay Zonu, MOFZ:

Malatya Ovacık Fay Zonu, NF: Nazimiye Fayı, KTB: Kuzey Türkiye Bölgesi, BAGB: Batı Anadolu Gerilme Bölgesi, OAOB: Orta Anadolu Ova Bölgesi, DASB: Doğu Anadolu Sıkışma Bölgesi,

Orta Anadolu "Ova" Bölgesi'nin doğu kesimlerini oluşturan KD yönlü sol yanal ve KB yönlü sağ yanal fayların, Kuzey Anadolu Fay Zonu (KAFZ) ve Doğu Anadolu Fay Zonu (DAFZ)'nun etkisi ile oluştuğu ileri sürülmüştür (Şengör, 1979; Şengör ve ark., 1985; Sançar ve ark., 2020). Bu araştırmaya konu olan çalışma alanı, kuzeyde sağ yanal KAFZ, güneydoğuda sol yanal DAFZ, batıda sol yanal Ovacık Fayı ve güneyde ise sağ yanal Nazimiye Fayı (NF) arasında yer alır (Şekil 1).

Çalışma alanı içerisindeki Munzur, Pülümür ve Peri nehirleri bölgedeki en büyük akaçlama alanlarına sahiptir. Kuzeydoğu-güneybatı akışlı Peri Nehir'i doğuda Tunceli'nin coğrafik sınırını oluştururken, yaklaşık kuzey-güney akışlı Munzur ve Pülümür nehirleri, Tunceli merkezinde birleșerek güneye doğru Munzur Nehir'i adıyla tek kol olarak devam eder. Nehrin güneye doğru devamında Dinar ve Rabat gibi daha küçük akaçlama alanlarına sahip dereler Munzur Nehir'ine bağlanırlar (Şekil 2). Söz konusu nehir ve derelerin vadileri aktif fay zonlarının da etkisiyle dar ve derin kazılmıştır. $\mathrm{Bu}$ nedenle Tunceli il sınırları içerisindeki sıcak ve mineralli sular bu fayların kontrolünde, vadi tabanlarından yüzeye çıkmaktadır. İl sınırları içerisindeki kaynaklardan sadece Pertek ilçesi Singeç vadisindeki sıcak ve mineralli sular Akkuş (2016) ile Öztüfekçi Önal ve Akkuş (2019) tarafindan, coğrafik olarak ilin D sınırını oluşturan Peri vadisindeki Kolan (Karakoçan-Elazı ğ) Kaplicaları ise Öztekin Okan (2004) tarafindan incelenmiştir. $\mathrm{Bu}$ incelemeler dişında, Munzur ile Pülümür vadilerindeki sıcak ve mineralli sularla ilgili yapılmış herhangi bir çalışma mevcut değildir. İldeki jeotermal sistemin özelliğinin belirlenmesi amaciyla; Munzur ve Pülümür vadilerindeki sıcak ve mineralli su kaynaklarının bulunduğu alan ve çevresinin jeolojik-yapısal özellikleri ile söz konusu kaynak sularının hidrojeokimyasal özellikleri araştırılmış ve elde edilen bulgular bu makalede sunulmuştur. 


\section{MATERYAL VE METOT Arazi Çalışmaları}

Çalışma alanı ve yakın civarında farklı ölçeklerde üretilen önceki jeoloji (Afshar, 1965; Granit ve Şener, 1986; Tarhan, 2008a, b) ve aktif fay haritaları (Duman ve ark., 2017), sayısal yükseklik modelleri ve uydu görüntüleri yardımı ile detaylandırıldıktan sonra arazi çalışmalarına başlanmıştır. Arazi çalışmaları kapsamında, araştırmanın amacına uygun olarak, inceleme alanındaki ana litolojik birimlerin sahasal yayılımı ve özellikleri incelenmiş ve ikincil fayların konumları belirlenmiştir. Mineralli su akiferinin hazne ve örtü kayaları ayırt edilerek, çalışmanın amacı doğrultusunda, MTA 1/25.000 ölçekli Jeoloji Haritalarından da faydalanılarak, inceleme alanının jeoloji haritası oluşturulmuştur. İlaveten; Munzur ve Pülümür nehirlerinin akaçlama alanları içerisindeki mineralli suların yüzeye çıkış alanları incelenerek örnekleme lokasyonları seçilmiştir. Seçilen lokasyonların kod (rakım) ve koordinat ölçümleri Magellan tipi (explorist 610) GPS cihazı ile yapılmış ve her bir lokasyondaki akifer birimlerin özellikleri incelenmiştir.

\section{Örnekleme, Analiz ve Değerlendirme Yöntemleri}

Munzur ve Pülümür vadileri akaçlama alanı içerisindeki 2 adet sıcak, 6 adet mineralli ve 2 adet (alanının kuzey ve güneyini temsil edecek) soğuk su (çeşme) kaynağından Şubat 2016'da yerinde ölçümler yapılmış ve kimyasal analizleri için su örnekleri alınmıştır. Yerinde yapılan ölçümlerde WTW Multi 3620 SET G portatif su ölçüm cihazı ve WTW SenTix ORP-900 probu kullanılarak pH, sicaklık, iletkenlik (EC), tuzluluk, redoks potansiyeli (ORP) ölçülmüş ve titrasyon yöntemiyle alkalinite belirlenmiştir. Örnekler katyon ve anyon analizleri için sırasıyla $50 \mathrm{ml}$ 'lik ve $500 \mathrm{ml}$ 'lik polietilen şişelere alınmıştır. Katyon analizlerinin yapılacağ su örnekleri şişelenirken $0.45 \mu \mathrm{m}$ PVDF su filtresi kullanılmış ve laboratuvara transferi sırasında katyon konsantrasyonlarını korumak için, $\mathrm{pH}<2$ olana kadar HNO3 (\% $\left.\begin{array}{ll}\% & 0.2\end{array}\right)$ ilave edilerek asitleştirilmiştir. Klor dahil katyon ve iz element analizleri ACME Analitik Laboratuvarında (Kanada) S200 paketi (72 element) olarak ICP-MS'de yaptırılmıştır. Anyon (SO4, NO2, NO3, NH3, Ortofosfat) analizleri ve toplam çözünmüş kat1 madde (TDS), toplam katı madde (TKM), toplam uçucu katı madde (TUKM) vs. analizleri ise Munzur Üniversitesi Çevre Mühendisliği Bölümü laboratuvarında yapılmıştır. Anyon analizleri yapılmadan önce sular, su filtrasyon seti yardımıyla $0,2 \mu-0,45 \mu$ geçirgenlikteki filtre kağıdından süzülerek, Shimadzu marka UV-1800 model spektrofotometre cihazında, APHA (2005) standardındaki metotlara göre yapılmıştır. Toplam uçucu katı madde analizi öncesinde ise süzme işlemi yapılmamıştır. Analiz sonuçları AquaChem 5.1 (Calmbach, 1997) hidrojeokimyasal ve PhreeqC (Parkhurst ve Appelo, 1999) kimyasal türleştirme programlarında değerlendirilmiştir. 2 adet sicak ve 2 adet mineralli suyun rezervuar sicaklıklarını tahmin etmek için, kimyasal jeotermometre hesaplamaları gerçekleştirilmiştir.

\section{SONUÇLAR}

\section{İncelenen Kaynakların Bölgesel Yapı ile İlişkisi}

Orta Anadolu "Ova" bölgesinin en doğu sınırına yakın yerde konumlanmış olan çalışma alanındaki en önemli aktif deformasyon kuşaklarından biri KB-doğrultulu sağ yanal Nazimiye Fay Zonu (NFZ)'dur. NFZ ile ilgili ilk görüş fayın $50 \mathrm{~km}$ uzunluğunda tek bir koldan oluştuğunu belirtmiştir (Duman ve ark., 2017). Yakın zamanda yapılan çalışmalar NFZ'nin birbirine paralel iki segmentten oluştuğunu ileri sürmüştür (Sançar ve ark., 2018). Kuzey'de yer alan kol (Duman ve ark., 2017'de çizilen kol) Beydere köyü kuzeyinden itibaren K70-80B uzanımında Gökçek köyüne kadar gelir. Yaklaşık $35 \mathrm{~km}$ uzunluğunda olan fayın bu parçası sıkışmalı ve genişlemeli büklüm geometrisine sahiptir. Gökçek civarında Pülümür nehrini yaklaşı $5 \mathrm{~km}$ sağ yanal öteleyen fay Gökçek'ten batıya doğru yaklaşık D-B doğrultusunda $15 \mathrm{~km}$ daha devam eder (Şekil 2). Güneyde yer alan kol ise Balcalı köyü güneyinden başlayarak Tunceli şehir merkezine kadar sıkışmalı büklüm geometrisi ile $35 \mathrm{~km}$ devam eder. $\mathrm{Bu}$ noktada güneye sıkışmalı sıçrama yaparak batıya doğru $25 \mathrm{~km}$ daha uzanır. Güney kolun Tunceli il merkezi civarındaki deformasyon genişliği ikincil faylar ile birlikte $15 \mathrm{~km}$ 'dir (Şekil 2). Bu deformasyon alanı içerisinde NFZ'ye paralel olarak konumlanmış ikincil fayların varlığ senaryo ile açıklanabilir. İlk senaryoya göre $\mathrm{KD}$ yönlü sol yanal ve KB yönlü sağ yanal bu faylar Anadolu Bloku doğusundaki diğer faylar gibi, KAFZ ve DAFZ'nin etkisi ile oluşmuş aktif 
yapılardır. KD yönlü olan sol yanal faylar NFZ tarafindan ötelenmiştir. İkinci senaryoya göre KD yönlü sol yanal ve KB yönlü sağ yanal bu ikincil faylar, deformasyon alanı geniş olan doğrultu atımlı faylarda gelişen sağ yanal RL ve sol yanal R'L faylarını temsil eder (Şekil 2 ve 3). Bu durumda fayın güney kolunun sıçrama bölgesinde yer alan ve güney kolu ile güneyinde yer alan Hozat fay1 arasında kalan sol yanal faylar R'L faylarını temsil eder. RL ve R'L fayları birbirlerine paralel iki sağ yanal fay arasında geliştikleri için bölgede oluşan deformasyonların bir kısmını üzerlerinde toplarlar (Şekil 2). Bu çalışma kapsamında belirlenen soğuk ve sıcak mineralli su kaynaklarının çıkış noktalarının dağılımının (Şekil 2), NFZ güney kolunun sıçrama yaptığ1 alanda yoğun olarak görülmesi, bu kaynakların bölgedeki ana ve ikincil fayların denetiminde yüzeye ulaştığını göstermektedir.

$\mathrm{Bu}$ kaynakların dişında kuzeyde Ovacık Fayı üzerinde yer alan Munzur gözeleri, NFZ kuzey kolunun batısında Munzur vadisi tabanında yer alan Halbori gözeleri ve doğusunda yer alan Doluca sicak su kaynağ1, NFZ güney kolunun doğu ucunda yer alan Bağın ve Kolan kaplıcaları ve güneybatıda Pertek Fayı üzerinde ye alan Pertek sicak ve mineralli su kaynakları da bölgedeki doğrultu atımlı fayların üzerinde yer almaktadır. Munzur ve Pülümür vadisi dışında kalan Bağın/Kolan ve Pertek alanlarındaki sıcak ve mineralli su kaynaklarının, bölgedeki fayların etkisiyle oluşmuş ikincil fayların kesişim alanlarından yüzeye çıktıkları, sırasıyla Öztekin Okan (2004) ve Akkuş (2016) tarafından yapılan çalışmalarda da açıkça görülmektedir.

\section{İnceleme Alanının Jeolojik Özellikleri}

Orta Anadolu "Ova" bölgesinin en doğu sınırına yakın yerde konumlanmış olan inceleme alanında yüzeylenen ve stratigrafik olarak en altta yer alan birim Karbonifer-Permiyen yaşta kabul edilen şist ve kristalize kireçtaşlarıdır (Şekil 3). Şistler inceleme alanının kuzeyinde geniş yayılımlar sunar ve daha çok ince kuvarsit bantları içeren serizit şistlerle temsil edilirler (Afshar, 1965; Granit ve Şener, 1986; Tarhan, 2008a, b). Şistlerin üstünde uyumlu olarak, Üst Permiyen fosilleri ile karakterize olan kristalize kireçtaşları ve mermerler yer almaktadır (Şekil 3) (Afshar, 1965). Üst Permiyen birimlerinin tabanındaki bu şistler Dinar vadisi içerisinde yer yer yüzeye çıkmıştır (Şekil 4a). Kristalize kireçtaşının alt kısmı şistlerle ardalanmalı iken üste doğru bu ardalanma kaybolur ve koyu kahverengi, organik maddece zengin masif kristalize kireçtaşları ve mermerlere geçer. $\mathrm{Bu}$ düzeyler inceleme alanında daha çok Munzur vadisi ve güneyindeki Dinar vadisi arasında geniş yayılım sunarlar. Maruz kaldıkları yoğun deformasyon sonrasında, kristalize kireçtaşları ve mermerlerde gelişen kırık ve çatlaklar ikincil kalsitlerle dolmuştur. İnceleme alanı kuzeyindeki benzer karbonatlı litolojiler, Keban metamorfikleri ve Munzur Karbonat Platformu olarak adlandırılmıştır (Çimen ve Öztüfekçi Önal, 2018). Dinar vadisinin GB'sında sadece dar bir alanda gözlenen üst Kretase yaşlı melanj dışında Munzur ve Dinar vadisi arasındaki alanlarda Mesozoyik birimleri bulunmaz. Çalışma alanı içerisinde Permiyen yaşlı kristalize kireçtaşları ve mermerlerin üzerinde uyumsuz olarak bulunan Eosen birimleri tabanda çakıltaşı ile başlar, üste doğru kumtaşı, çamurtaş1 ardalanmasının eğemen olduğu gri renkli fliş istifiyle devam eder ve kireçtaşı düzeyleriyle sonlanır (Şekil 4b, c) Munzur vadisinin doğusunda ve Dinar vadisinin güneyinde Eosen birimlerinin üzerine uyumsuz olarak Miyosen yaşlı denizel kireçtaşları ve yer yer sarımsı-gri renkli marnlar gelmektedir. Kireçtaşları alt Miyoseni karekterize eden fosil içermeleri ve marnlar ise organik maddece zengin düzeyleri ile karekterize olurlar. Miyosen sonlarına doğru bölgede etkili olan yoğun volkanik faaliyetin sonucunda, inceleme alanındaki Eosen ve Miyosen sedimanları MiyosenPliyosen piroklastikleri ve lav akıntıları (Aktağ ve ark., 2019) tarafindan örtülmüştür. Çalışma alanındaki Pliyo-Kuvaterner birimleri, Munzur ve Pülümür vadilerinin batı kenarlarında sıcak sular tarafından oluşturulmuş yaygin eski traverten çökelimleri ve taraçalar ile temsil edilir. Munzur ve Pülümür vadilerinde ana derenin her iki tarafinda basamaklı olarak taraça seviyelerinin görülmesi bölgede devam eden yükselime işaret etmektedir. Dinar vadisinde ise bunlara ilaveten güncel traverten çökelimi hala devam etmektedir. 


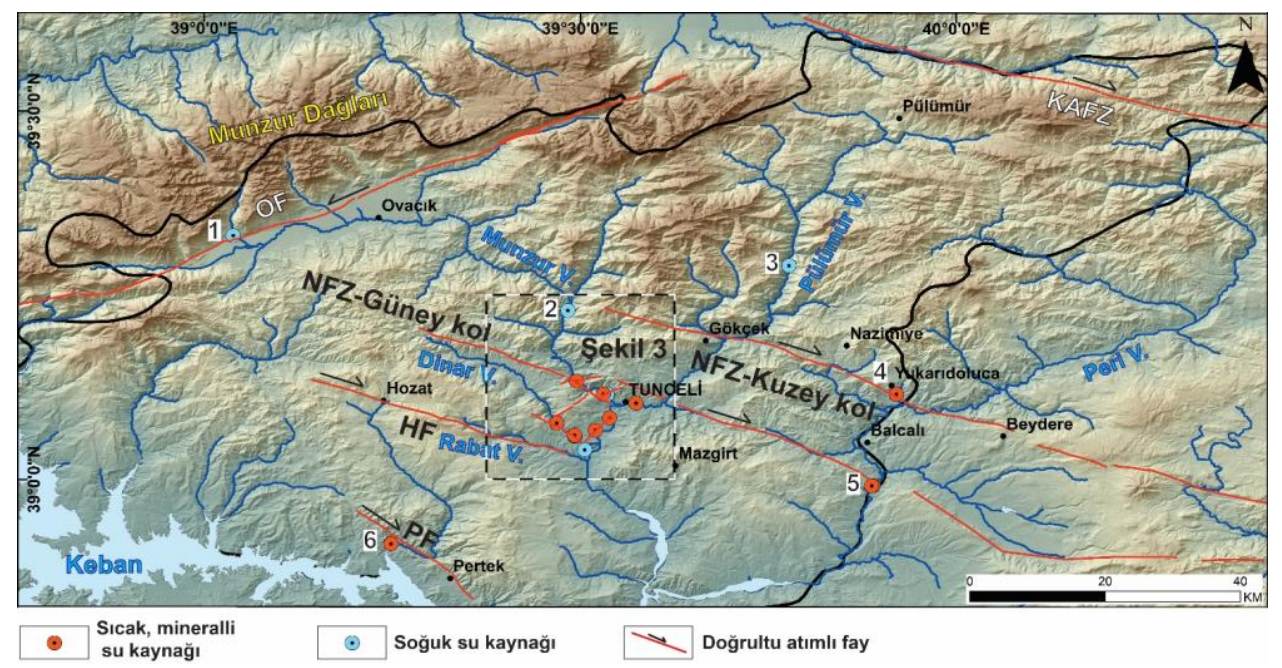

Şekil 2. Tunceli'deki aktif faylar (Duman ve ark., 2017'den değiştirilerek alınmıştır) üzerinde yer alan sıcak ve soğuk mineralli su kaynaklarıın konumları (1: Munzur Gözeleri, 2: Halbori Gözeleri, 3: Zağge Kaynağı, 4: Doluca Kaplıcası, 5: Bağın/Kolan Kaplıcaları, 6: Pertek Jeotermal Alanı, KAFZ: Kuzey Anadolu Fay Zonu, NFZ: Nazimiye Fay Zonu, OF: Ovacık Fayı, HF: Hozat Fayı, PF: Pertek Fayı, Beyaz kesikli Kare Şekil 3'deki haritanın yerini sınırlar).

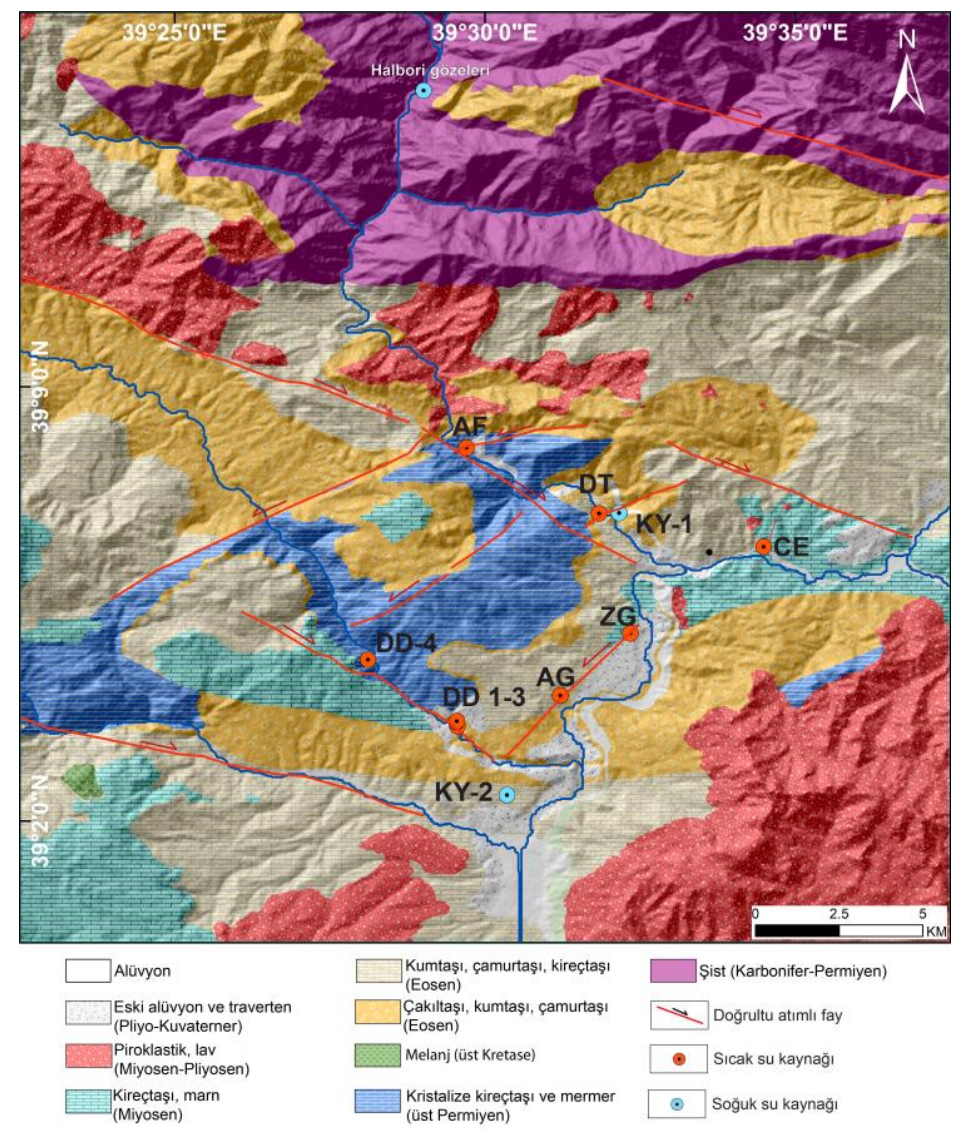

Şekil 3. İnceleme alanının jeoloji haritası (MTA 1/25000 ölçekli Jeoloji haritası baz alınarak arazide modifiye edilmiştir) ve araş̧ırılan kaynak sularının dağılımı (AF: Anafatma, DT: Dikilitaş, KY-1: Munzur vadlsl Kemerbel çeşmesi, KY-2: Aktuluk köy çeşmesi, CE: Cemevi, ZG: Ziheng, AG: Askeriye Girişi, DD1-4: Dinar kaynakları) 


\section{İnceleme Alanının Hidrojeolojik Özellikleri}

İnceleme alanında yeraltı suyu taşıyan en önemli akifer birim Permiyen yaşlı kristalize kireçtaş1 ve mermerdir. Eosen ve Miyosen kireçtaşları ile Miyosen-Pliyosen yașlı lavlar da kalınlık ve yayılımlarına bağlı olarak daha sınırlı miktarlarda yeraltı suyu taşımaktadır. Permiyen yaşlı kristalize kireçtaşı ve mermerlerin birincil gözeneklilikleri düşüktür. Ancak, bölgede etkin olan tektonik faaliyetler sonucunda oldukça çatlaklı ve kırıklı bir yapı kazanmış ve bu yapı karstlaşmayı da artırmıştır. Sonuçta geçirimlilik ve ikincil porozite artarak oldukça yüksek yeraltı suyu depolama kapasitesi kazanmıştır. Eosen ve Miyosen yaşlı kireçtaşları yine çatlaklı ve karstik boşluklu olmaları nedeniyle su depolayabilmektedir. MiyosenPliyosen yaşlı lavların kırıklı- çatlaklı yapısı da sinırlı da olsa su depolamasına izin vermektedir. Permiyen yaşlı Kristalize kireçtaşı ve mermerler üzerinde drenaj sıklığının çalışma alanındaki diğer birimlere kıyasla daha az olması da yeraltı suyunun yağıştan beslenmesinin yüksek olduğunu göstermektedir. İnceleme alanındaki söz konusu bu akifer biriminin eşdeğeri olan ve Bağın/Kolan kaplıcalarının akiferi olan Keban Metamorfitleri'ne ait kristalize kireçtaş1 ve mermerlerin de su depolama kapasitesinin yüksek olduğu Öztekin Okan (2004) tarafindan vurgulanmıştır.

İnceleme alanındaki Eosen flişi ve MiyosenPliyosen yaşlı piroklastik kayaçların (tüflerin) eşdeğeri olan ve Bağın/Kolan civarındaki marn ve tüflerde sirasiyla toplam porozitenin \%13-19 ile \%20-37 arasında değiştiği Öztekin Okan (2004) tarafindan açıklanmıştır.

Tunceli meteoroloji istasyonunun 1950-2015 yı1ları arasındaki 65 yıllık yağış verileri dikkate alındığında yıllık ortalama toplam yağışın $861,4 \mathrm{~mm}$ olduğu görülmektedir. Bu istasyonun verileri dikkate alınarak Akkuş (2016) tarafından, su bütçesi hesaplamalarına göre yıllık 393,17 mm'lik suyun yeraltına süzüldüğü açıklanmıştır. Bu değer yıllık ortalama yăğşın yaklaşık \%46'sının yeraltına süzüldüğünü ifade etmektedir. Munzur ve Halbori gözeleri gibi büyük debili yeraltısuyu kaynakları Permiyen kireçtaşı ve mermer akiferinin suyunu boşaltmaktadır. Geçirimliliği yüksek ve karstik özelliği olan bu kireçtaşlarının geniş alanlar kaplayan beslenme bölgesi ilin kuzeyindeki Munzur dağ silsilesidir. Baskın olarak kar şeklinde görülen yağıştan beslenen kaynaklardan, kurak dönemlerde dahi önemli miktarda boşalım olmaktadır. Bu kaynakların debilerinin mevsimsel yağışlardan fazla etkilenmemesi, sularının derin dolaşımlı ve Permiyen kristalize kireçtaşı ve mermer akiferinin depolama hacmının büyük olduğunu düşündürmektedir. Eosen ve Miyosen yaşlı geçirimli kırıntılı ve karbonatl kayalardan ise beslenme alanının büyüklüğüne bağlı olarak Pülümür vadisi (Örn. Zağge kaynağı, Şekil 2) ve daha güneyinde birçok değişken debili soğuk su kaynakları bulunmaktadır. Munzur ve Pülümür vadilerindeki sıcak ve mineralli su kaynaklarının ana akifer kayasını da Permiyen yaşlı kristalize kireçtaşı ve mermerler, örtü kayasını ise Eosen yaşlı çamurtaşı, marn gibi geçirimsiz kırıntılı kayalar ve MiyosenPliyosen yaşlı tüfler oluşturmaktadır. Ancak, Munzur ve Dinar vadisi arasındaki çoğu alanda, akifer kaya durumundaki Permiyen kireçtaşı ve mermerlerin üzerinde, geçirimsiz örtü kayası bulunmamaktadır (Șekil 3). $\mathrm{Bu}$ araștırma kapsamında hidrojeolojik gözlemlerin yapıldığ sıcak ve mineralli su kaynaklarının arazi görüntüleri Şekil 5'de, hidrojeokimyası incelenen kaynakların koordinat, kot ve akifer özellikleri ise Çizelge 1'de verilmiştir. 

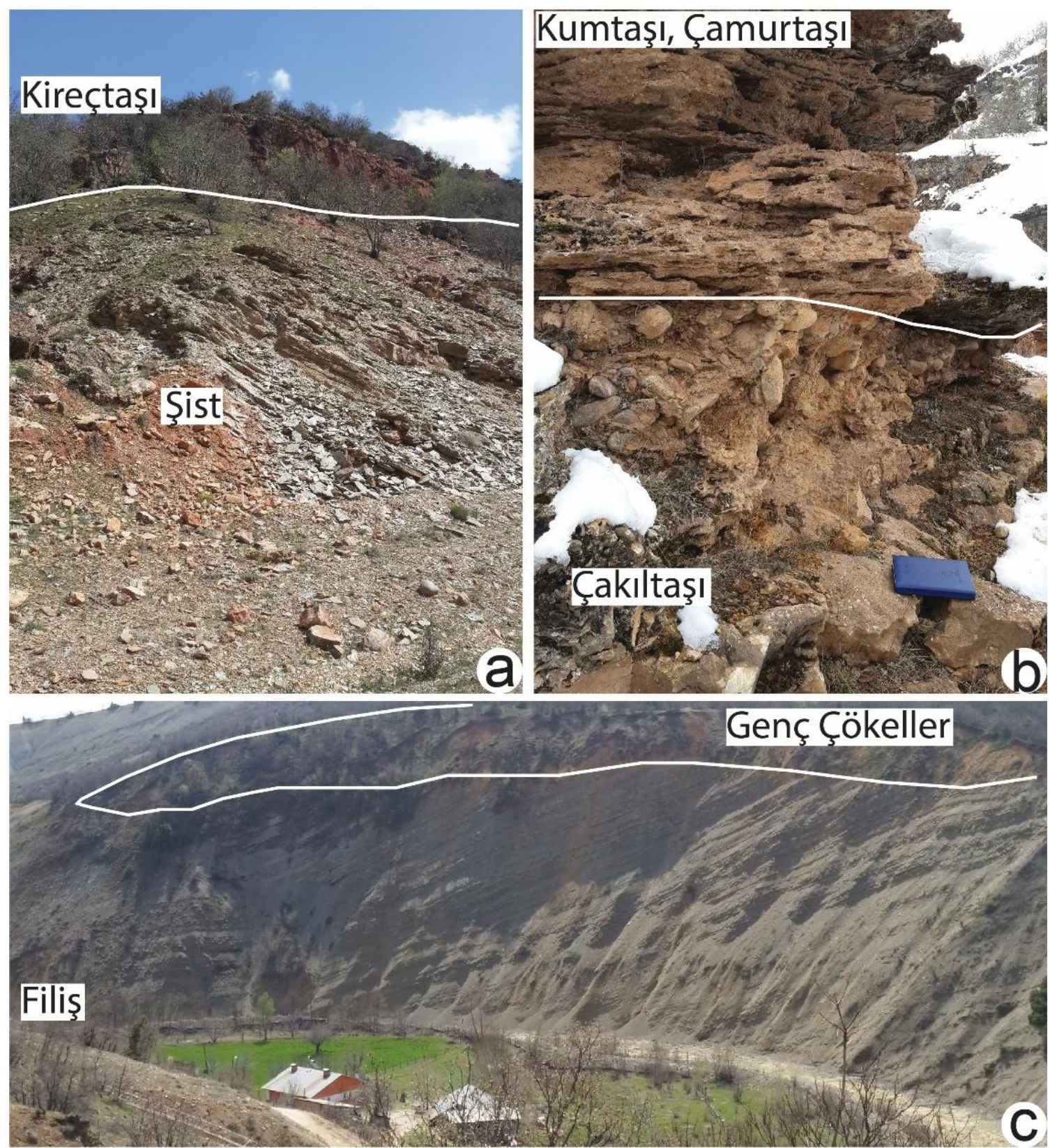

Şekil 4. (a) Karbonifer-Permiyen yaşlı şist ve üst Permiyen yaşlı kristalize kireçtaşı dokanağı, (b) Eosen çakıltaşı, kumtaşı ve çamurtaşı ardalanması ve (c) Eosen flişi ve genç çökeller arasındaki dokanak. 
Tablo 1. Incelenen sicak, mineralli ve soğuk su kaynaklarl.

\begin{tabular}{|c|c|c|c|c|}
\hline Örnek & $\begin{array}{l}\text { Kaynak } \\
\text { çıkış kodu } \\
\quad(\mathbf{m})\end{array}$ & Enlem & Boylam & Akifer özellikleri \\
\hline DD-3 & 940 & 39.492 & 39.059 & $\begin{array}{l}\text { Eosen çakıltaşı tarafından örtülmüş olan Permiyen kristalize } \\
\text { kireçtaşı akiferinden, Dinar vadisi tabanından yüzeye ulaşan sıcak } \\
\text { su kaynağı }\end{array}$ \\
\hline $\mathrm{AG}$ & 949 & 39.520 & 39.067 & $\begin{array}{l}\text { Eosen kireçtaşı tarafindan örtülmüş olan Permiyen kristalize } \\
\text { kireçtaşı akiferinden yüzeye ulaşan sıcak su kaynağı }\end{array}$ \\
\hline DD-1 & 946 & 39.492 & 39.060 & $\begin{array}{l}\text { Eosen çakıltaşı tarafindan örtülmüş olan Permiyen kristalize } \\
\text { kireçtaşı akiferinden, Dinar vadisi yamacından yüzeye ulaşan } \\
\text { mineralli su kaynağı }\end{array}$ \\
\hline DD-2 & 944 & 39.492 & 39.058 & $\begin{array}{l}\text { Eosen çakıltaşı tarafindan örtülmüş olan Permiyen kristalize } \\
\text { kireçtaşı akiferinden Dinar vadisi yamacından yüzeye ulaşan } \\
\text { mineralli su kaynağı }\end{array}$ \\
\hline $\mathrm{ZG}$ & 935 & 39.539 & 39.083 & $\begin{array}{l}\text { Munzur Nehir’inin eski alüvyon çökellerinden yüzeye çıkan } \\
\text { mineralli su kaynağı }\end{array}$ \\
\hline $\mathrm{CE}$ & 930 & 39.574 & 39.103 & $\begin{array}{l}\text { Permiyen kristalize kireçtaşı akiferinden geldiği düşünülen, Eosen } \\
\text { kireçtaşının tabanından yüzeye ulaşan mineralli su kaynağı }\end{array}$ \\
\hline DT & 917 & 39.530 & 39.116 & $\begin{array}{l}\text { Permiyen kristalize kireçtaşı akiferinden Munzur Nehir’i } \\
\text { tabanından yüzeye çıkan mineralli su kaynağı }\end{array}$ \\
\hline $\mathrm{AF}$ & 940 & 39.495 & 39.133 & $\begin{array}{l}\text { Permiyen kristalize kireçtaşı akiferinden yüzeye ulaşan mineralli } \\
\text { su kaynağı }\end{array}$ \\
\hline KY-1 & 938 & 39.535 & 39.116 & Eosen flişinden yüzeye çıkan soğuk su kaynağı (çeşme) \\
\hline KY-2 & 946 & 39.505 & 39.04 & Eosen flişinden yüzeye çıkan soğuk su kaynağı (çeşme) \\
\hline
\end{tabular}

İncelenen Kaynak Sularının Hidrojeokimyasal Özellikleri

İncelenen soğuk suların (KY-1 ve KY-2) yüzey sıcaklıkları birbirine çok yakın değerlerdedir (Çizelge 2). Mineralli su kaynaklarından Atatürk mahallesindeki ZG kaynağının çıkış noktasındaki havuz suyunun ölçüm zamanında donmuş olması, DT ve AF'ye Munzur nehir suyunun ve DD-1, DD-2 kaynaklarına ise yamaçtan süzülen kar sularının karışması nedeniyle, sıcaklıkları olduğundan daha düşük değerlerde ölçülmüştür (Çizelge 2). Yüzey suyu ile karışımın olmadığ DD-3 ve AG sıcak suları ile CE mineralli suyun sicaklık değerleri ise değişkenlik göstermez. Soğuk sular ve CE mineralli suyu nötre yakın, diğer tüm sıcak ve mineralli sular asidik özelliktedir (Çizelge 2). Bölgedeki benzer sistemlerden boşalan Bağın/Kolan kaplıcaları (Öztekin Okan, 2004) ile benzer, fakat Pertek sicak ve mineralli su kaynaklarının değerlerinden (Öztüfekçi Önal ve Akkuş, 2019) yüksektir. 

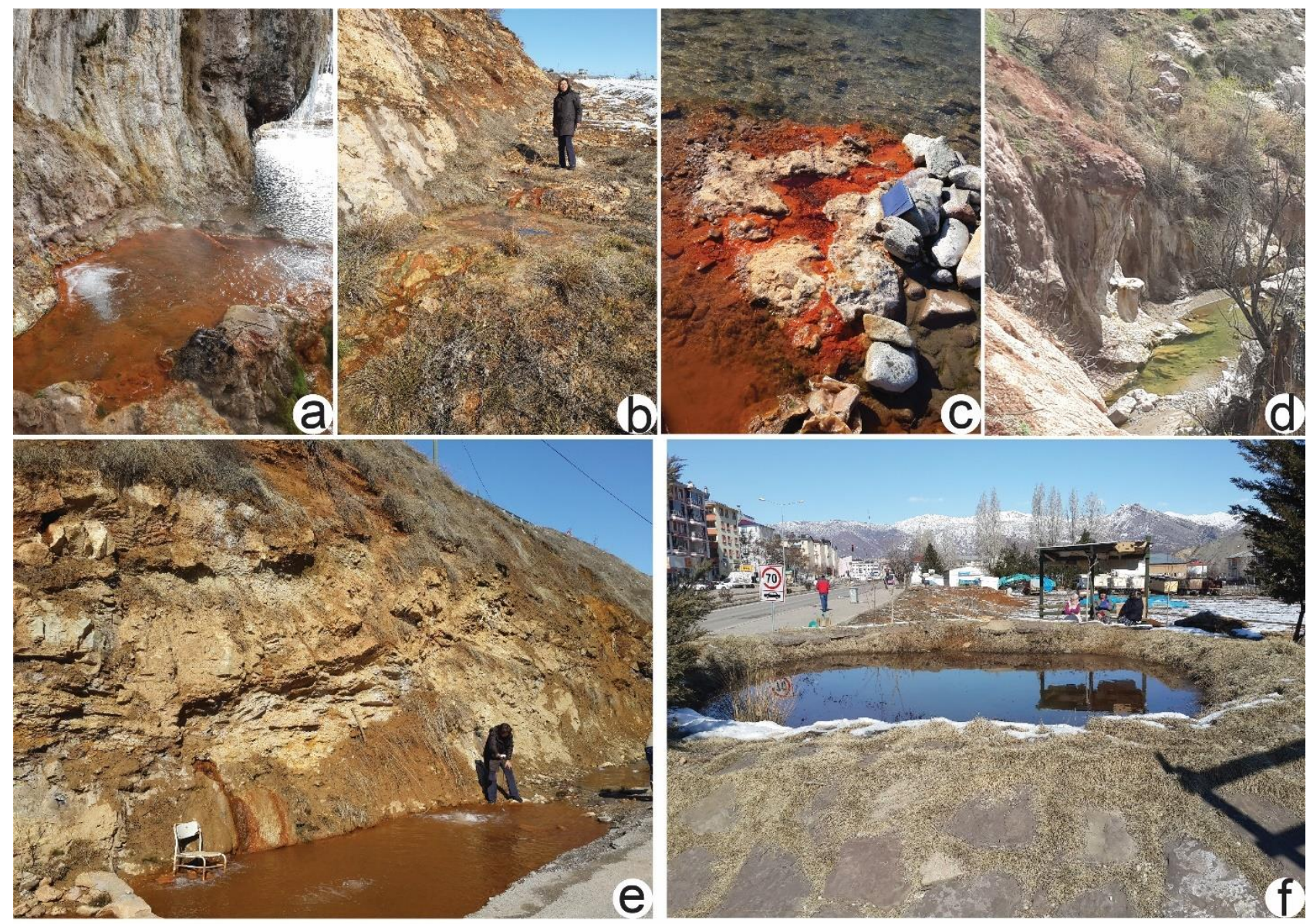

Şekil 5. İnceleme alanındaki sıcak ve mineralli kaynak alanlarının arazi görüntüleri (a) Dinar Vadisi (DD-3), (b) Askeriye Girişi (AG), (c) Dikilitaş (DT), (d) Dinar Vadisi güncel traverten oluşumu, (e) Cemevi (CE) ve (f) Ziheng (ZG) kaynakları

İyonların topluca görülmesi, kökenlerinin karşılaştırılması amacıyla, örneklenen tüm suların anyon ve katyonları meq/l cinsinden hesaplanarak Piper (üçgen) ve Schoeller (yarı logaritmik) diyagramlarında (Şekil 6) gösterilmiştir (Piper, 1944). Piper diyagramındaki izdüşüm yerlerine göre incelenen tüm kaynakların kökenleri aynı olup, CaMg-HCO3'lı sular sınıfındadır (Şekil 6a). Bu durum, sıcak, mineralli ve soğuk suların hazne kayasının kireçtaş1 ve mermerler olduğunu desteklemektedir. Scholler diyagramında ise, soğuk su kaynakları (KY-1 ve KY-2) ve yüzey suyu karışımının daha fazla olduğu mineralli su kaynaklarında (ZG ve DT), Cl- ve $\mathrm{Na}+\mathrm{K}$ oranlarının daha düşüktür (Şekil 6b). Fakat, tüm suların iyonlarını birleştiren doğruların birbirlerine paralel olmas1, ayn1 akiferden beslendiğine işaret etmektedir. Anyon-katyon dizilimleri ise sirasıly $\mathrm{rCa}+2>\mathrm{rMg}+2>\mathrm{r}(\mathrm{Na}++\mathrm{K}+)$ ve $\mathrm{rHCO} 3->\mathrm{rSO} 4-2>\mathrm{rCl}-$ şeklindedir (Şekil 6b). Bu dizilim karbonatlı kayaçlardan gelen suların dizilimlerine benzemektedir. $\mathrm{Cl}, \mathrm{HCO} 3$ ve $\mathrm{SO} 4$ iyonlarının $\% \mathrm{mg} / \mathrm{l}$ değerleri dikkate alınarak sınıflandırıldığı üçgen diyagramda (Şekil 7a) ise hem sicak hem de mineralli sular birbirinin çok yakınında ve çevresel sular grubunda yer almıştır. $\mathrm{Bu}$ da, incelenen sicak ve mineralli suların meteorik kökenli olabileceğini düşündürmektedir. İlaveten Giggenbach (1988) tarafindan sicak suların hazne kaya sıcaklıklarının saptanması ve suların ilişkide olduğu kayalarla olan denge durumlarının belirlenmesi için kullanılan Na-K-Mg üçgen diyagramında (Şekil $7 b$ ) ise, incelenen tüm sıcak ve mineralli sular, su-kayaç ilişkisinin dengede olmadığ 1 ham sular alanının $\mathrm{Mg}$ köşesinde dar bir alanda kalmışlardır. 
Tablo 2. Incelenen sicak (DD-3, AG), mineralli (DD-1, DD-2, ZG, CE, DT, AF) ve soğuk (KY-1, KY-2) suların yerinde ve laboratuvarda yapılan bazı analiz sonuçları. Belirtilmeyen konsantrasyonlar mg/l dir. ITAS: Insani Tüketim Amaçlı Su limit değerleridir. Bu değerler; Insani Tüketim Amaçlı Sular Hakkında Yönetmelikte Değişiklik Yapılmasına Dair Yönetmelik ( ITASHY, 2013), TS 266 ve WHO (*işaretli olanlar) kabul edilebilir maksimum değerleridir.

\begin{tabular}{|c|c|c|c|c|c|c|c|c|c|c|c|}
\hline Parametre & ITAS & DD-3 & AG & DD-1 & DD-2 & ZG & CE & DT & $\mathbf{A F}$ & KY-1 & KY-2 \\
\hline $\mathrm{pH}$ & $\leq 9,5-6,5 \leq$ & 6,22 & 6,14 & 6,2 & 5,98 & 6,45 & 6,8 & 5,96 & 6,0 & 6,66 & 7,28 \\
\hline $\mathrm{T}\left({ }^{\circ} \mathrm{C}\right)$ & - & 30,4 & 31 & 20,8 & 20,8 & 6,6 & 19,9 & 15,6 & 20,3 & 13,7 & 13,9 \\
\hline $\mathrm{EC}(\mu \mathrm{S} / \mathrm{cm})$ & 2500 & 2290 & 2930 & 2341 & 2258 & 1516 & 2855 & 2786 & 2231 & 891 & 471 \\
\hline $\mathrm{ORP}(\mathrm{mV})$ & - & 34 & 45 & 44 & 46 & 16 & 41 & 46 & 43 & 6 & -29 \\
\hline Tuzluluk (psu) & - & 1593 & 1575 & 1244 & 1200 & 0,770 & 1524 & 1468 & 1185 & 0,478 & 0,272 \\
\hline $\mathrm{Na}^{+}$ & 200 & 109,71 & 119,26 & 80,81 & 88,77 & 8,29 & 174,6 & 7,17 & 130,56 & 5,58 & 5,83 \\
\hline $\mathrm{K}^{+}$ & 12 & 24,79 & 26,66 & 16,67 & 18,3 & 2,71 & 20,82 & 1,52 & 14,95 & 1,52 & 0,79 \\
\hline $\mathrm{Ca}^{2+}$ & 200 & 542,76 & 545,84 & 402,64 & 375,2 & 263,85 & 475,34 & 756,77 & 359,47 & 167,54 & 81,39 \\
\hline $\mathrm{Mg}^{2+}$ & 50 & 90,68 & 88,54 & 68,94 & 85,73 & 65,7 & 56 & 37,83 & 48,8 & 30,43 & 12,77 \\
\hline $\mathrm{Cl}^{-}$ & 250 & 121 & 130 & 83 & 97 & 6 & 205 & 2 & 155 & 2 & 1 \\
\hline $\mathrm{SO}_{4}^{2-}$ & 250 & 80 & 83,33 & 73,33 & 88,33 & 70 & 75 & 66,67 & 118,33 & 70 & 63,33 \\
\hline $\mathrm{HCO}_{3}^{-}$ & - & 2280 & 2160 & 1650 & 1630 & 1115 & 2020 & 2590 & 1480 & 780 & 360 \\
\hline $\mathrm{NH}_{3}^{-}$ & 0,50 & 0,03 & 0,06 & 0,05 & 0,02 & 0,04 & 0,09 & 0,01 & 0,05 & 0,03 & 0,04 \\
\hline $\mathrm{NO}_{2}^{-}$ & 0,50 & 0,0003 & 0 & 0,0003 & 0,0007 & 0 & 0,0007 & 0,0003 & 0,0017 & 0 & 0 \\
\hline $\mathrm{NO}_{3}^{-}$ & 50 & 0,06 & 0,22 & 0,3 & 0,1 & 0,07 & 1,15 & 0,01 & 0,47 & 0,25 & 2,01 \\
\hline Ortofosfat & - & 0,13 & 0,13 & 0,25 & 0,13 & 0,13 & 0,13 & 0,25 & 0,5 & 0,38 & 0,13 \\
\hline $\mathrm{Si}$ & - & 11,54 & 11,54 & 10,78 & 10,78 & 6,21 & 22,5 & 8,52 & 9,27 & 7,25 & 9,43 \\
\hline $\mathrm{SiO}_{2}$ & - & 24,69 & 24,69 & 23,06 & 23,06 & 13,28 & 48,13 & 18,23 & 19,83 & 15,51 & 20,17 \\
\hline $\mathrm{Li}$ & - & 0,55 & 0,58 & 0,41 & 0,44 & 0,03 & 0,59 & 0,03 & 0,55 & 0,01 & 0,003 \\
\hline$\% \mathrm{Na}$ & - & 13,52 & 14,51 & 13,25 & 14,35 & 2,21 & 22,28 & 0,82 & 21,59 & 2,42 & 5,02 \\
\hline SAR & - & 1,15 & 1,25 & 0,98 & 1,08 & 0,12 & 2,02 & 0,07 & 1,71 & 0,1 & 0,16 \\
\hline Sertlik $\left(\mathrm{CaCO}_{3}^{-}\right)$ & $500^{*}$ & 172,7 & 172,6 & 128,65 & 128,9 & 92,85 & 141,6 & 204,4 & 109,76 & 54,3 & 25,55 \\
\hline Ikatyon (meq/l) & - & 39,95 & 40,39 & 29,67 & 30,1 & 19 & 36,45 & 41,22 & 28,01 & 11,14 & 5,38 \\
\hline इanyon (meq/l) & - & 42,45 & 40,8 & 30,91 & 31,29 & 19,9 & 40,45 & 43,89 & 31,09 & 14,29 & 7,24 \\
\hline TDS & $1000^{*}$ & 1600 & 1600 & 1400 & 1500 & 700 & 1500 & 1300 & 1500 & 600 & 300 \\
\hline TKM & - & 2000 & 1900 & 1500 & 1500 & 900 & 1800 & 1900 & 1500 & 600 & 300 \\
\hline TUKM & - & 200 & 200 & 200 & 300 & 100 & 100 & 100 & 200 & 100 & 100 \\
\hline $\mathrm{Fe}$ & 0,20 & $<0.01$ & 3,14 & $<0.01$ & $<0.01$ & 0,03 & $<0.01$ & $<0.01$ & $<0.01$ & $<0.01$ & $<0.01$ \\
\hline $\mathrm{Mn}$ & 0,05 & 0,08 & 0,08 & 0,003 & 0,004 & 0,14 & 0,35 & 0,65 & 0,0008 & 0,0004 & 0,0009 \\
\hline $\mathrm{Al}$ & 0,20 & 0,009 & 0,02 & 0,004 & 0,008 & 0,02 & 0,008 & $<0,001$ & 0,39 & 0,003 & 0,03 \\
\hline As & 0,01 & 0,33 & 0,96 & 0,12 & 0,19 & 0,006 & 0,008 & 0,003 & 0,11 & 0,0006 & 0,002 \\
\hline B & 1,00 & 7 & 6,72 & 5,18 & 5,68 & 0,24 & 8,7 & 0,17 & 7,3 & 0,12 & 0,05 \\
\hline $\mathrm{Cu}$ & 2 & 0,001 & 0,002 & 0,001 & 0,001 & 0,001 & 0,002 & 0,001 & 0,002 & 0,0009 & 0,001 \\
\hline $\mathrm{Pb}$ & 0,01 & $<0,0001$ & 0,0002 & $<0,0001$ & $<0,0001$ & 0,0002 & 0,0001 & $<0,0001$ & 0,0001 & $<0,0001$ & 0,0002 \\
\hline $\mathrm{Cr}$ & 0,05 & 0,04 & 0,02 & 0,04 & 0,03 & 0,01 & 0,01 & 0,04 & 0,02 & 0,003 & 0,003 \\
\hline
\end{tabular}



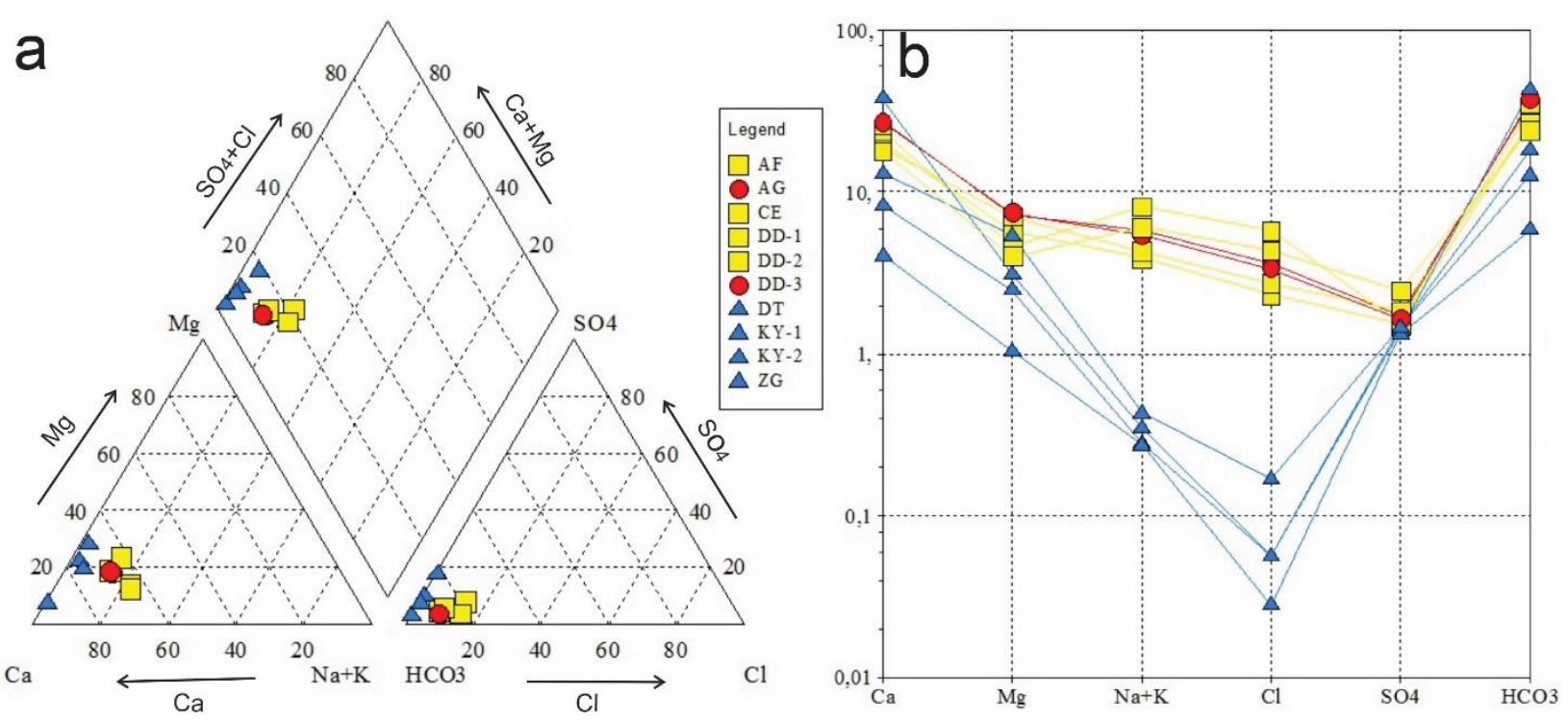

Şekil 6. İncelenen suların (a) Piper ve (b) Scholler diyagramlarındaki görünümleri.
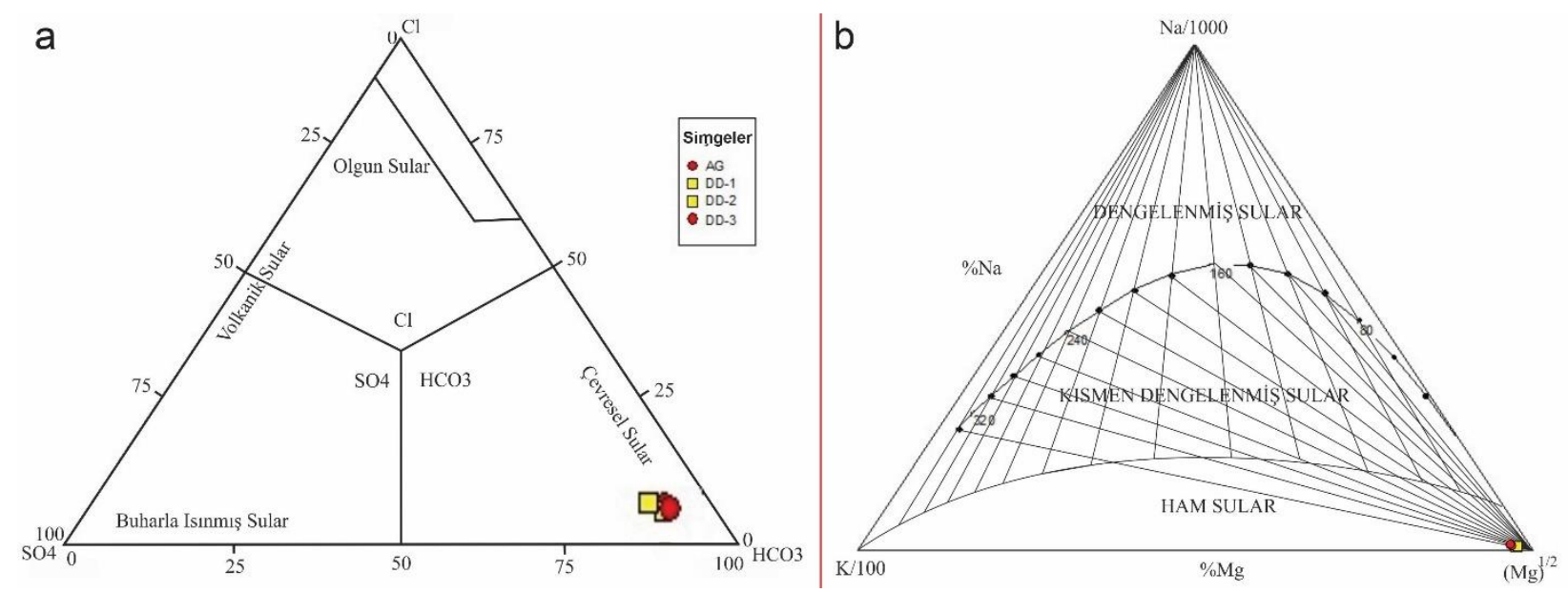

Şekil 7. Sıcak ve mineralli suların (a) Nicholson, (1993) ve (b) Na-K-Mg üçgen diyagramındaki (Giggenbach, 1988) konumları.

İncelenen tüm sularda baskın katyon olan kalsiyum (Ca2+), çalışma alanında Permiyen, ve muhtemelen Eosen ve Miyosen yaşlı kireçtaşı ve killi kireçtaşları içindeki $\mathrm{CO} 2$ içeren suların dolaşımı sırasında, CaCO3'ün çözünmesi ile suya eklenmiştir. Yüksek sicaklığa sahip jeotermal sularda $\mathrm{Mg}$ derişimi düşük (0,01-0,1 ppm) iken, çalışma alanındaki sıcak sularda 91 ppm'e, mineralli sularda ise 86 ppm'e kadar çıkmaktadır. Bu durum sıcak ve mineralli suların beslenme alanındaki Permiyen yaşlı mermerlerin dolomit bileşenlerinin olabileceğine ve meteorik sulardan karışıma işaret edebilir. İlaveten, lityum (Li) değerleri ise oldukça düşük $(0,03-0,59 \mathrm{ppm})$ tür. Suda çözünmüş halde bulunan $\mathrm{Ca}$ ve $\mathrm{Mg}$ bileşiklerinden ileri gelen Fransız Sertlik derecelerine (Çizelge 2) göre, soğuk su kaynakları oldukça sert-sert sular, soğuk ve sicak mineralli sular ise çok sert sular sınıfındadır. İncelen tüm sularda $\mathrm{Cr}, \mathrm{Pb}$ ve $\mathrm{Cu}$ gibi çoğu ağır metallerin derişimleri düşüktür (Çizelge 2). Sicak sulardan $A G$ örneğinde $\mathrm{Fe}$, mineralli sulardan $\mathrm{CE}$ örneğinde alüminyum, CE ve DT örneklerinde Mn derişimleri yüksektir. İlaveten, sıcak ve mineralli suların çoğunda As ve B derişimleri ise oldukça yüksektir. 
Bölgedeki su sisteminde yüksek $A s$ ve $B$ derişimlerinin varlığ 1 , inceleme alanının GB'sındaki Pertek sicak ve mineralli su kaynaklarında ve Munzur nehir suyunda, sırasıyla Öztüfekçi Önal ve Akkuș (2019) ile Çimen ve ark. (2015) tarafindan da açıklanmıştır. Bölgede ciddi bir endüstriyel veya insan kaynaklı kirletici etkinin olmadığ bilindiğinden, As ve $\mathrm{B}$ derişimlerinin yüksekliği (Çimen ve ark., 2015 tarafindan da açıklandığı gibi) Munzur nehri akaçlama alanındaki $\mathrm{Cu}-\mathrm{Pb}-\mathrm{Zn}$ cevherleşmesinden kaynaklandığı düşünülmektedir. İncelenen tüm mineralli ve sıcak sularda $\mathrm{Cl}$ konsantrasyonları, bölgedeki Pertek ve Bağın/Kolan kaplıca sularına benzer şekilde çok düşüktür. Nicholson (1993) tarafindan açıklandığı gibi düşük Cl- değerlerinin, sisteme modern yeraltısuyu girișiminin olabileceğine işaret edebilir. $\mathrm{CE}$ ve $\mathrm{AF}$ mineralli sularındaki bir miktar $\mathrm{Cl}$ - ve $\mathrm{Na}+\operatorname{artıș1}$ (Şekil 2), bu suların dolaşım alanı derinliğindeki magmatik kayaçların plajiyoklas gibi Na'ca ve mika, amfibol gibi Cl'ca zengin minerallerinin alterasyonu sonucunda olabilir. Bu değerlere göre, $\mathrm{CE}$ mineralli suyunun yeraltındaki dolaşım süresi, incelenen diğer sulardan daha uzun olabilir. İncelenen sıcak suların mineral doygunluk indeksleri, Pertek sıcak sularına (Öztüfekçi Önal ve Akkuş, 2019) benzer şekilde kalsit, dolomit ve aragoniti çökeltici, jips ve anhidriti çözündürücü özelliktedir.

Çalışılan alanda hazne sıcaklığının doğrudan ölçüldüğü herhangi bir araștırma veya üretim kuyusu bulunmamaktadır. Bu nedenle, hazne sıcaklığının tahmin edilebilmesi için, çalışılan sıcak suların ve iki mineralli suyun (DD-1, DD-2) kimyasal analizleri kullanılarak jeotermometre hesaplamaları yapılmıştır (Çizelge 3). Çizelge 3'de görüldüğü gibi hem sicak hem de mineralli sularda $\mathrm{Na} / \mathrm{K}$ jeotermometresi $300{ }^{\circ} \mathrm{C}^{\prime}$ ye yakın hazne akışkan sicaklığı verirken, kuvars ve $\mathrm{Na}-\mathrm{K}-\mathrm{Ca}(\mathrm{Mg}$ düzeltmeli) jeotermometre sonuçları $87-64{ }^{\circ} \mathrm{C}$ arasında sicaklıklar vermiştir. Sicak suların ve mineralli suların ham sular (Şekil 7b) olması nedeniyle yaklaşık $300{ }^{\circ} \mathrm{C}$ hazne akışkan sıcaklığ 1 veren $\mathrm{Na} / \mathrm{K}$ jeotermometresini dikkate almak uygun olmayacaktır. $120{ }^{\circ} \mathrm{C}^{\prime}$ nin altında silisin allotrop çeşidi olan kalsedon jeotermometresi (buhar kaybı yok) ise sıcak su kaynaklarının çıkış sıcaklığından sadece $10-20{ }^{\circ} \mathrm{C}$ daha yüksek olan ve daha kabul edilebilir hazne kaya akışkan sıcaklıkları vermiştir (Çizelge 3). Doğrudan ölçülen hazne kaya akışkan sıcaklıkları olmadığı için, birbiriyle daha uyumlu kuvars ve Na-K-Ca jeotermometre sonuçları dikkate alındığında, Munzur ve Dinar vadisi arasındaki Permiyen kireçtaşı/mermer akiferinin üst seviyelerinde $40{ }^{\circ} \mathrm{C}$ 'ye yakın, üzerinde geçirimsiz örtünün var olduğu alanlarda ise (özellikle şistlerle dokanağa yakın taban seviyelerinde) $70-90^{\circ} \mathrm{C}$ arasında hazne kaya akışkan sıcaklığının olabileceği öngörülebilir.

\section{İncelenen Suların Kullanım Özellikleri}

Pertek sicak ve mineralli suları ile Munzur ve Pülümür vadisindeki $A F$ ve $C E$ mineralli suları yöre halkı tarafından şifalı su kabul edilerek içilmektedir. $\mathrm{CE}$ hariç, incelenen sıcak ve mineralli suların $\mathrm{pH}$ değerleri TS 266 (Çizelge 2), EPA ve WHO içme suyu standartlarının altındadır. CE, DT mineralli suları ve AG sıcak suyunun EC değerleri ise içme suyunun kabul edilebilir maksimum değerinden fazladır. ZG mineralli suyu hariç, tüm sıcak ve mineralli suların TDS değerleri WHO'nun içme suyu sınır değerinin üzerindedir (Çizelge 2). İncelenen tüm suların sülfat, amonyak, nitrit ve nitrat değerlerinde sorun olmadığı ve sertlik (CaCO3) değerlerinin $500 \mathrm{mg} / \mathrm{L}$ olan WHO maksimüm sınır değerinden düşük olduğu görülmektedir (Çizelge 2). İncelenen sıcak ve mineralli suların tümünde $\mathrm{Ca}$ derişimi, insani tüketim amaçlı suların sınır değerlerinden fazladır. İlaveten, $\mathrm{K}$ derişimi DT ve $\mathrm{ZG}$ dışındaki, $\mathrm{Mg}$ derişimi ise yine DT ve kısmen AF dışındaki mineralli sularda ve sıcak sularda TS 266 sinır değerlerinden fazladır. Sadece $\mathrm{Fe}$ bakımından AG sicak suyu, Al bakımından ise AF mineralli suyu ve Mn bakımından ZG, CE ve DT mineralli suları sınır değerlerin üzerindedir. $Z G$ ve DT hariç diğer mineralli ve sıcak sular B açısından sınır değerlerin oldukça üzerindedir. As ise $\mathrm{ZG}, \mathrm{CE}$, DT haricindeki mineralli ve sicak sularda TS 266, EPA ve WHO içme suyu standardından $(0,01 \mathrm{mg} / \mathrm{L})$ 10-100 katı fazladır (Çizelge 2). Günümüzde şifalı su olarak içilen $\mathrm{CE}$ ve $\mathrm{AF}$ mineralli suları (yukarıda açıklanan birçok parametrenin TS 266, EPA ve WHO içme suyu sınır değerlerinin çok üzerinde olmas1 nedeniyle), içmek için uygun değildir. Çünkü; İncelenen sicak ve mineralli su kaynaklarının doğrudan içme suyu olarak tüketilmesi doku bozulmalarına, dolaşım sistemi problemlerine ve kanser riskinin yükselmesine neden olabilir.

Sulama suyu olarak kullanma kriterlerini belirlemek amacıyla; İncelenen tüm suların sodyum 
zararı olarak bilinen sodyum adsorbsiyon oranları (SAR) ve toplam tuzluluk göstergesi olan özgül elektriksel iletkenlik (EC) değerleri (Çizelge 2) ABD Tuzluluk Laboratuvarı Diyagramına (Şekil 8a) yerleștirilmiștir. Diyagramda; İnceleme alanının güneyini temsil eden soğuk su kaynağı (KY-2) C2S1 (orta tuzlu, az sodyumlu) sinıfinda olduğu için her türlü sulamada, inceleme alanının kuzeyini temsil eden soğuk su kaynağının (KY-1) ise C3-S1 (tuzlu, az sodyumlu) sinıfinda yer aldığı için tuza dayanıklı bitkilerin sulanmasında kullanılabileceği görülmüştür. Benzer şekilde, $Z G$ ve $A F$ mineralli su kaynakları da C3-S1 (tuzlu, az sodyumlu) sinıfinda olup, ZG tuza dayanıklı bitkilerin sulanmasında kullanılabilir. Ancak, AF'nin kullanımında, C4-S1 (çok tuzlu, az sodyumlu) sınıfa yakınlığı ve B değerinin yüksekliği (Çizelge 2) de dikkate alınmalıdır. Diğer mineralli sular ve sıcak sular ise C4-S1 (çok tuzlu, az sodyumlu) sinıfinda olup, sadece tuza çok dayanıklı bitkilerin sulamasında kullanılabilir. EC ve \%Na değerleri kullanılarak sulamaya uygun olup olmadığının belirlenmesi için oluşturulmuş Wilcox diyagramında ise (Şekil 8b), incelenen soğuk sular (KY-1, KY-2) Çok iyi, ZG mineralli suyu İyi-kullanılabilir alanda yer alırken, ZG dışındaki mineralli sular ve sıcak sular Şüphelikullanılamaz alanda yer almışlardır

Tablo 3. Sıcak (DD-3 ve AG) ve mineralli (DD-1 ve DD-2) suların bazı çözünürlük jeotermometreleri ile elde edilen hazne akışkan sicaklıkları.

\begin{tabular}{|c|c|c|c|c|}
\hline Çözünürlük Jeotermometreleri & DD-3 & $\mathrm{AG}$ & DD-1 & DD-2 \\
\hline $\mathrm{SiO}_{2}$ (Kuvars-Buhar kaybı yok) & 72 & 72 & 69 & 69 \\
\hline $\mathrm{SiO}_{2}$ (Kuvars-Maksimum buhar kaybı) & 76 & 76 & 74 & 74 \\
\hline $\mathrm{SiO}_{2}$ (Kalsedon-Buhar kaybı yok) (Fournier,1977) & 40 & 40 & 37 & 37 \\
\hline $\mathrm{SiO}_{2}$ (Kalsedon-100 C'de Max. Buhar Kayb1) (Arnorsson vd.,1983) & 50 & 50 & 47 & 47 \\
\hline $\mathrm{Na} / \mathrm{K}$ (Arnorsson vd., 1983) & 289 & 288 & 280 & 280 \\
\hline $\mathrm{Na} / \mathrm{K}$ (Fournier 1977) & 311 & 310 & 300 & 300 \\
\hline $\mathrm{Na} / \mathrm{K}$ (Giggenbach et al.,1983) & 307 & 306 & 298 & 298 \\
\hline Na-K-Ca Jeotermometresi (Fournier ve Truesdell, 1973) & 85 & 87 & 81 & 64 \\
\hline Na-K-Ca (Mg düzeltmesiz; Fournier ve Truesdell, 1973) & 187 & 188 & 179 & 182 \\
\hline $\mathrm{Na} / \mathrm{Li}(\mathrm{Cl}<0,3 \mathrm{~mol} / \mathrm{kg})$ (Fouillac and Michard, 1981) & 137 & 135 & 138 & 136 \\
\hline $\mathrm{Na} / \mathrm{Li}(\mathrm{Cl}>0,3 \mathrm{~mol} / \mathrm{kg})($ Fouillac and Michard, 1981) & 132 & 130 & 133 & 131 \\
\hline Li/Mg Jeotermometresi (Kharaka ve Mariner, 1989) & 247 & 243 & 225 & 257 \\
\hline
\end{tabular}




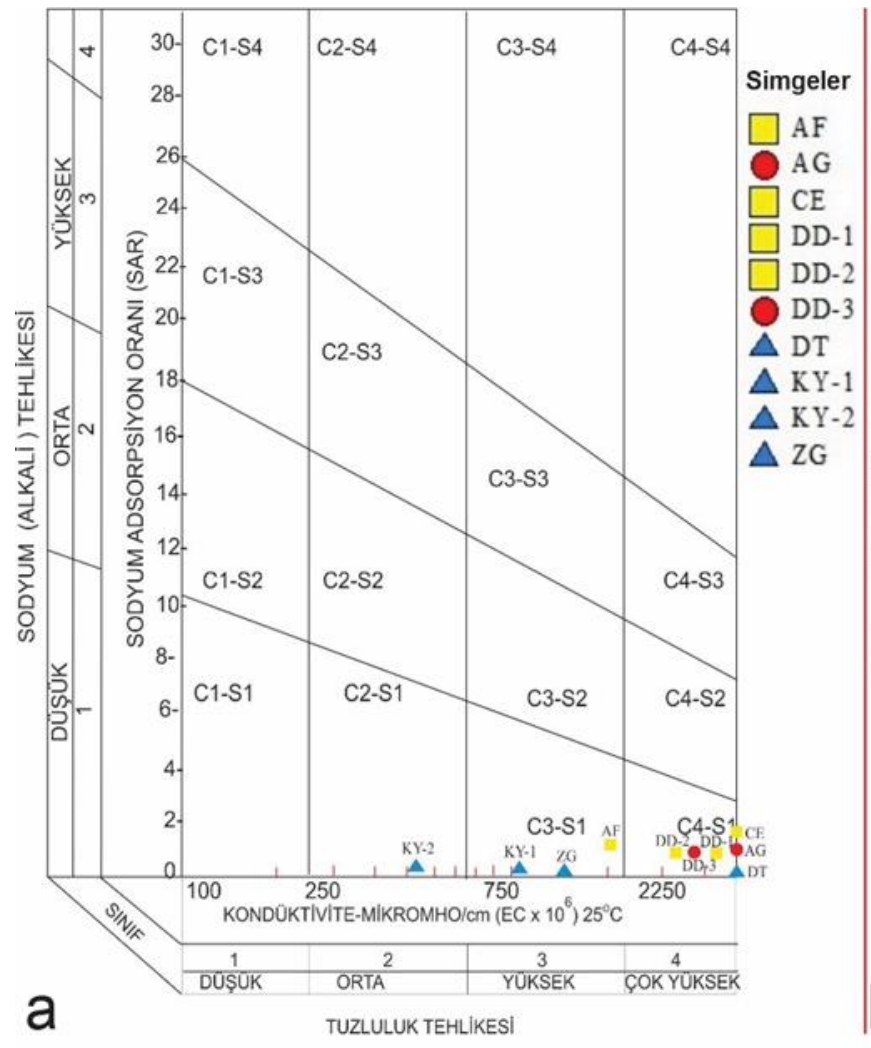

Şekil 8. İncelenen suların (a) ABD Tuzluluk Laboratuvarı (A) ve (b) Wilcox diyagramlarındaki konumları. alanda örtü kayacı olmadığından jeotermal sistem açık hale gelmiştir. İncelenen mineralli ve sıcak su kaynaklarının, çok kırıklı çatlaklı Permiyen kireçtaş1/mermerleri ve Senozoyik kireçtaşlarından derine sızarak ısınan suların, fay ve çatlaklar aracılığıyla tekrar yüzeye erişmesiyle oluştukları düşünülmektedir. Pertek ve Bağın/Kolan kaplıca sularına benzer şekilde, inceleme alanındaki sıcak ve mineralli suların $\mathrm{Mg}$ derişimleri ve düşük $\mathrm{Cl}$ içerikleri (Çizelge 2) kaynakları besleyen suların meteorik kökenli olabileceklerine işaret etmektedir. Çünkü, Cl- derin rezervuar sularından şarj olan ve soğuk su karışımının minumum olduğu jeotermal sularda yüksektir. DD-1, DD-2 ve ZG mineralli sularındaki HCO3 iyonunun, sicak sulara (DD-3, AG) nazaran daha az olması, bu sular yüzeye erişirken, nispeten daha fazla meteorik su karışımının olduğuna işaret etmektedir. Tüm sıcak ve mineralli suların kimyasal yapısı Ca-Mg-HCO3 tipindedir ve içinde bulunduğu kayaçlarla kimyasal dengeye erişmemiştir.

İncelenen sicak ve mineralli suların doğrudan hazne akışkan sıcaklığının ölçüleceği sondaj mevcut olmadığından, farklı jeotermometrelerle hesaplanan hazne kaya akışkan sıcaklıkları arasında büyük farklılıklar oluşmuştur (Çizelge 3). Jeolojik ve 
hidrojeolojik

parametreler

birlikte

değerlendirildiğinde, Permiyen yaşlı kireçtaş1mermer akiferinin şistlerle olan taban dokanağında hazne kaya akışkan sıcaklığının $70{ }^{\circ} \mathrm{C}$ 'nin üzerine çıkabileceği öngörülmektedir. Akiferden yüzeye doğru gelen sicak suyun soğuması veya meteorik suların karışımı ile kimyasal yapısı değişeceğinden, gerçek hazne akışkan sıcaklığının belirlenmesi için, Munzur ve Dinar vadisi arasındaki alanda Permiyen kireçtaş1/mermer haznesine kadar inen araştırma sondaj kuyularının açılması, kuyu içi akışkan sıcaklıklarının ölçülmesi ve bu suların kimyasal analiz sonuçlarının da sıcak kaynak suları ile birlikte aynı jeotermometre hesaplamalarında değerlendirilerek karşılaştırılması gerekmektedir. İlaveten; alterasyon minerallerinin ortaya çıkarılması ve çevresel izotoplarla kalitatif olarak değerlendirilmesi hazne kaya akışkan sıcaklıklarının belirlenmesine katkı sağlayacaktır.

İncelenen soğuk ve sicak mineralli sular doğrudan içme kürü olarak kullanılmamalıdır. Yöre halkı tarafindan içilen AF ve CE kaynaklarının, "içme suyuna uygun olmadığı" yetkililerce ilan edilmelidir. As değeri daha düşük olan soğuk mineralli CE kaynağının fiziksel ve kimyasal parametrelerinin içme standartlarına uygun hale getirilerek mineralli su olarak şişelenmesi amaçlandığında ise detay bakteriyolojik analizlerin yapılması, antropojenik kirlilikten etkilenmeyecek şekilde kaynağın kaptajlanması, koruma alanları etüdünün yapılması, kullanım sonrası açığa çıkacak akışkanın çevre limitlerini dikkate alarak deşarj edilmesi önemlidir. Günümüzde, Dinar deresine boşalan DD-3 kaynağı, kaynak yakınındaki uygun alanlarda (Örn. Munzur Üniversitesi Kampüsü) yapılacak tesislerle, banyo ve tedavi amaçlı olarak sağlık turizmine kazandırılmalıdır.

\section{AÇIKLAMALAR}

Makalenin geliştirilmesine katkı sağlayan hakemlere, arazi ve laboratuvar çalışmalarına katılan Öğr. Gör. Ali Önal ve Jeoloji Yük. Müh. Aysun Akkuş'a, bazı laboratuvar analizlerine yardımcı olan Arş. Gör. Deniz Demirbilek'e desteklerinden dolayı teşekkür ederiz.

\section{ÇIKAR ÇATIŞMASI BEYANI}

Yazar bu makale ile ilgili herhangi bir çıkar çatışması bildirmemektedir.

\author{
ARAŞTIRMA VE YAYIN ETİĞİ BEYANI \\ Yazar bu çalışmanın araştırma ve yayın etiğine \\ uygun olduğunu beyan eder.
}

\section{KAYNAKLAR}

Afshar, F. A., 1965. Geology of Tunceli-Bingöl Region of Eastern Turkey. Bulletin of the Mineral Research and Exploration, 65: 65, s. 33-44.

Akan, B., 2002. Modeling of the Afyon Ömer-Gecek geothermal system. Jeoloji Mühendisliği Dergisi, 26: 2, s. 31-52.

Akkuş, A., 2016. Pertek Jeotermal Alanının Hidrojeokimyasal Özelliklerinin İncelenmesi. [Yüksek Lisans: Munzur Üniversitesi.

Akkuş, İ., H., A., Ceyhan, S., Dilemre, A., ve Tekin, Z., 2005. Türkiye Jeotermal Kaynakları Envanteri. Envanter Serisi-201. MTA, Ankara.

Aktağ, A., Öztüfekçi Önal, A., Sayit, K., 2019. Geochemistry of the post-collisional Miocene mafic Tunceli Volcanics, Eastern Turkey: Implications for the nature of the mantle source and melting systematics. Geochemistry, 79: 1, s.113-129.

Akyuz, H. S., Altunel, E., Karabacak, V., ve Yalciner, C. C., 2006. Historical earthquake activity of the northern part of the Dead Sea fault zone, southern Turkey. Tectonophysics, 426: 3-4, s. 281-293.

Alacali, M., 2018. Hydrogeochemical investigation of geothermal springs in Erzurum, East Anatolia (Turkey). Environmental Earth Sciences, 77: 24, s. 802. 10.1007/s12665-018-7986-1

Alacalı, M., 2013. Hydrogeological modeling of Balçova geothermal system. [PhD: Isparta Süleyman Demirel University.

APHA (2005) Standard Methods for the Examination of Water and Wastewater. 21st Edition, American Public Health Association/American Water Works Association/Water Environment Federation, Washington DC.

Arnorsson, S Gunnlaugsson, E, Svavarsson, H., 1983. The chemistry of geothermal waters in Iceland. III. Chemical geothermometry in geothermal investigations. Geochimica et Cosmoschimica Acta, 47, s 567-577.

Avagyan, A., Sosson, M., Karakhanian, A., Philip, H., Rebai, S., Rolland, Y., Melkonyan, R., ve Davtyan, V., 2010. Recent tectonic stress evolution in the Lesser Caucasus and adjacent regions. Geological Society, London, Special Publications, 340: 1, s. 393. https://doi.org/10.1144/SP340.17

Bülbül, A., Özen, T., ve Tarcan, G. J. A. J. o. B., 2011. Hydrogeochemical and hydrogeological investigations of thermal waters in the AlasehirKavaklidere area (Manisa-Turkey). African Journal 
of Biotechnology, 10: 75, s. 17223-17240, DOI: 10.5897/AJB11.3050

Cakin, A., Gokcen, G., Eroğlu, A. E., ve Baba, A., 2012. Hydrogeochemistry and Environmental Properties of Geothermal Fields. Case Study: Balçova, IzmirTurkey. Energy Sources, Part A: Recovery, Utilization, and Environmental Effects, 34: 8, s. 732 745. https://doi.org/10.1080/15567031003681903

Calmbach, L., 1997. AquaChem Computer Code-Version 3.7.42, Waterloo Hydrogeologic. Waterloo, Ontario, Canada N2L 3L3.

Chorowicz, J., Dhont, D., ve Gündogdu, N., 1999. Neotectonics in the eastern North Anatolian fault region (Turkey) advocates crustal extension: mapping from SAR ERS imagery and Digital Elevation Model. Journal of Structural Geology, 21: 5, s. 511-532. https://doi.org/10.1016/S01918141(99)00022-X

Çimen, O. ve Öztüfekçi Önal, A., 2018. Preliminary geochemical data of the mafic rocks from the Ovacik and Pülümür Ophiolite Zone (Eastern Anatolia, Turkey): implications for the geodynamic evolution of the northern Neotethyan Ocean. Ofioliti, 43: 2, s 103-116.

Çimen, O., Toksoy-Köksal, F., Öztüfekçi-Önal, A., Örgün-Tutay, $\quad$ Y. 2015. Environmental Contamination of Heavy Metals and Chrysotile Asbestos in the Munzur and Pülümür Streams (Tunceli/Turkey). Ofioliti. Vol. 40 (1), 27-36.

Duman, T. Y., Çan, T., Emre, Ö., Kadirioğlu, F. T., Başarır Baştürk, N., Kılıç, T., Arslan, S., Özalp, S., Kartal, R. F., Kalafat, D., Karakaya, F., Eroğlu Azak, T., Özel, N. M., Ergintav, S., Akkar, S., Altınok, Y., Tekin, S., Cingöz, A., ve Kurt, A. İ., 2017. Türkiye Sismotektonik Haritası, Özel Yayın Serisi-34, Maden Tetkik Arama Genel Müdürlüğü, Ankara-Türkiye.

Duman, T. Y., ve Emre, Ö., 2013. The East Anatolian Fault: geometry, segmentation and jog characteristics. in Geological Development of Anatolia and the Easternmost Mediterranean Region, London, 372, s. 495-529, eds. Robertson, A. H. F., Parlak, O., ve Ünlügenç,, U. C., Geological Society, Special Publications. https://doi.org/10.1144/SP372.14

EPA (U.S Environmental Protection Agency), 2008. National Primary Drinking Mater Regulations. U.S. EPA Office of Water, http://water.epa.gov/drink/contaminants/index.cfm

Faccenna, C., Becker, T. W., Jolivet, L., ve Keskin, M., 2013. Mantle convection in the Middle East: Reconciling Afar upwelling, Arabia indentation and Aegean trench rollback. Earth and Planetary Science Letters, $\quad 375, \quad$ s. 254-269. http://dx.doi.org/10.1016/j.epsl.2013.05.043
Firat Ersoy, A., ve Çalik Sönmez, S., 2014. Hydrogeochemical and isotopic characteristics of the Ilica geothermal system (Erzurum, Turkey). Environmental Earth Sciences, 72: 11, s. 4451-4462. 10.1007/s12665-014-3345-z

Fouillac, C. ve Michard, G., 1981. Sodium/Lithium ratio in water applied to the geothermometry of geothermal waters. Geothermics, 10, s 55-70.

Fournier, R.O. ve Truesdell, A.H., 1973. An Empirical Na-K-Ca Geothermometer for Natural Waters. Geochimica et Cosmochimica Acta, 37, s 12551275.

Fournier, R.O., 1977. Chemical geotermometers and mixing models for geothermal systems. In: Proceedings of the Symposium on Geothermal Energy, Centro Scientific Programme, Ankara, s 199-210.

Giggenbach, W. F., Gonantini, R., Jangi, B.L., Truesdell, A.H., 1983. Isotopic and Chemical Composition of Parbati Valley Geothermal Discharges, NW Himalaya, Indiana. Geothermics, 12, s 199-222.

Giggenbach, W. F., 1988. Geothermal solute equilibria. Derivation of Na-K-Mg-Ca geoindicators. Geochimica et Cosmochimica Acta, 52: 12, s. 27492765. https://doi.org/10.1016/0016-7037(88)901433

Granit, S., ve Şener, M., 1986. Tunceli Havzası'nın Jeolojisi ve Petrol Olanakları. MTA Genel Müdürlüğü, Enerji Hammade Etüt ve Arama Dairesi Başkanlığı Rapor No. 8284, Ankara

Hall, J., Aksu, A. E., Elitez, I., Yaltırak, C., ve Çifçi, G., 2014. The Fethiye-Burdur Fault Zone: A component of upper plate extension of the subduction transform edge propagator fault linking Hellenic and Cyprus Arcs, Eastern Mediterranean. Tectonophysics, 635: Supplement C, S. 80-99. https://doi.org/10.1016/j.tecto.2014.05.002.

ITASHY (2013). İnsani Tüketim Amaçlı Sular Hakkında Yönetmelikte Değişiklik Yapılmasına Dair Yönetmelik, EK 1: İçme-kullanma suları için parametreler ve sınır değerleri. Resmi Gazete, Sayı: 28580.

Kharaka, T.K. ve Mariner, R.H., 1989. Chemical Geothermometers and their Application to formation waters from sedimentary basins. In: N.D. Naser and T.H. McCulloh (Eds.). Thermal History of Sedimentary Basins Methods and Case Histories. Springer Verlag, s. 99-117.

Koçyiğit, A., ve Beyhan, A., 1998. A new intracontinental transcurrent structure: The Central Anatolian Fault Zone, Turkey. Tectonophysics, 284, s. 317-336. https://doi.org/10.1016/S00401951(97)00176-5

Köse, R., 2005. Research on the generation of electricity from the geothermal resources in Simav region, 
Turkey. Renewable Energy, 30: 1, s. 67-79. https://doi.org/10.1016/j.renene.2004.04.004

Köse, R., 2007. Geothermal energy potential for power generation in Turkey: A case study in Simav, Kutahya. Renewable and Sustainable Energy Reviews, 11: 3, $\quad$ s. $497-511$. https://doi.org/10.1016/j.rser.2005.03.005

Le Pichon, X., Chamot-Rooke, N., L., S., Noomen, R., ve Veis, G., 1995. Geodetic determination of the kinematics of central Greece with respect to Europe: Implications for eastern Mediterranean tectonics. Journal of Geophysical Research: Solid Earth, 100, s. 12675-12690. https://doi.org/10.1029/95JB00317

Le Pichon, X., ve Kreemer, C., 2010. The Miocene-toPresent Kinematic Evolution of the Eastern Mediterranean and Middle East and Its Implications for Dynamics. Annual Review of Earth and Planetary Sciences, 38: 1, s. 323-351. https://doi.org/10.1146/annurev-earth-040809152419

Magri, F., Akar, T., Gemici, U., ve Pekdeger, A., 2010. Deep geothermal groundwater flow in the Seferihisar-Balçova area, Turkey: results from transient numerical simulations of coupled fluid flow and heat transport processes. Geofluids, 10: 3, s. 388-405. 10.1111/j.1468-8123.2009.00267.x

McClusky , S., Balassanian, S., Barka, A., Demir, C., Ergintav, S., Georgiev, I., Gurkan, O., Hamburger, M., Hurst, K., Kahle, H., Kastens, K., Kekelidze, G., King, R., Kotzev, V., Lenk, O., Mahmoud, S., Mishin, A., Nadariya, M., Ouzounis, A., Paradissis, D., Peter, Y., Prilepin, M., Reilinger, R., Sanli, I., Seeger, H., Tealeb, A., Toksöz, M. N., ve Veis, G., 2000. Global Positioning System constraints on plate kinematics and dynamics in the eastern Mediterranean and Caucasus. Journal of Geophysical Research, 105: B3, s. 5695-5719. https://doi.org/10.1029/1999JB900351

McKenzie, D., 1972. Active Tectonics of the Mediterranean Region. Geophysical Journal of the Royal Astronomical Society, 30: 2, s. 109-185. https://doi.org/10.1111/j.1365-246X.1972.tb02351.x

Mutlu, H., 1998. Chemical geothermometry and fluidmineral equilibria for the Ömer-Gecek thermal waters, Afyon area, Turkey. Journal of Volcanology and Geothermal Research, 80: 3, s. 303-321. https://doi.org/10.1016/S0377-0273(97)00051-6

Nicholson, K., 1993. Geothermal fluids: chemistry and exploration techniques. Berlin Heidelberg: Springer Berlin Heidelberg.

Nyst, M., ve Thatcher, W., 2004. New constraints on the active tectonic deformation of the Aegean. Journal of Geophysical Research: Solid Earth, 109: B11, s. n/a-n/a. https://doi.org/10.1029/2003JB002830

Özeren, M. S., ve Holt, W. E., 2010. The dynamics of the eastern Mediterranean and eastern Turkey.
Geophysical Journal International, 183: 3, s. 11651184. https://doi.org/10.1111/j.1365246X.2010.04819.X

Öztekin Okan, Ö., 2004. Kolan (Karakoçan) sıcak su kaynakların hidrojeokimyasal incelemesi. [Doktora: Frrat Üniversitesi, $114 \mathrm{~s}$.

Öztüfekçi Önal, A., Akkuş, A., 2019. Hydrogeochemical Characteristics of Hot and Cold Waters in the Tunceli Pertek Geothermal Area. Int. J. Pure Appl. Sci. 5 (1), 53-71, DOI: 10.29132/ijpas.546499

Parkhurst, D. L. ve Appelo, C.A.J., 1999. User's quide to PHREEQC (versiyon 2):. A computer program for speciation, batch-reaction, one-dimensional transport, and inverse geochemical calculations. U.S. Geological Survey Water-Resources Investigations Report, USGS, 99-4259, Reston Virginia.

Philip, H., Cisternas, A., Gvishiani, A., ve Gorshkov, A., 1989. The Caucasus: an actual example of the initial stages of continental collision. Tectonophysics, 161: 1-2, s. 1-21. https://doi.org/10.1016/00401951(89)90297-7

Piper, A.M., 1944. A graphic procedure in the geochemical interpretation of water-analyses. First published: June/September, https://doi.org/10.1029/TR025i006p00914

Reilinger, R., McClusky, S. C., Vernant, P., Lawrence, S., Ergintav, S., Cakmak, R., Ozener, H., Kadirov, F., Guliev, I., Stepanyan, R., Nadariya, M., Hahubia, G., Mahmoud, S., Sakr, K., ArRajehi, A., Paradissis, D., Al-Aydrus, A., Prilepin, M., Guseva, T., Evren, E., Dmitrotsa, A., Filikov, S. V., Gomez, F., AlGhazzi, R., ve Karam, G., 2006. GPS constraints on continental deformation in the Africa-ArabiaEurasia continental collision zone and implications for the dynamics of plate interactions. J. Geophys. Res., 111: B5, s. B05411. https://doi.org/10.1029/2005JB004051

Reilinger, R. E., McClusky, S. C., Oral, M. B., King, R. W., Toksoz, M. N., Barka, A. A., Kinik, I., Lenk, O., ve Sanli, I., 1997. Global Positioning System measurements of present-day crustal movements in the Arabia-Africa-Eurasia plate collision zone. J. Geophys. Res., 102: B5, s. 9983-9999. https://doi.org/10.1029/96jb03736

Sançar, T., Sunal, G., ve Erturaç, M. K., 2018, An Example For The Re-Activation Of The PreExisting Structures During The Westward Extrusion Of The Anatolian Scholle: Nazimiye Fault, Geological Congress of Turkey 2019: Ankara,Turkey.

Sançar, T., Zabcı, C., Akçar, N., Karabacak, V., Yeşilyurt, S., Yazıcı, M., Serdar Akyüz, H., Önal, A. Ö., Ivy-Ochs, S., Christl, M., ve Vockenhuber, C., 2020. Geodynamic importance of the strike-slip faults at the eastern part of the Anatolian Scholle: Inferences from the uplift and slip rate of the 
Malatya Fault (Malatya-Ovacık Fault Zone, eastern Turkey). Journal of Asian Earth Sciences, 188, s. 104091. https://doi.org/10.1016/j.jseaes.2019.104091

Şaroğlu, F., Emre, Ö., ve Kuşçu, İ., 1992. Türkiye Diri Fay Haritasi (Active Faut Map of Turkey), scale 1:2000000, one sheet. Maden Tetkik ve Arama Genel Müdürlüğü,.

Searle, M. P., Chung, S.-L., ve Lo, C.-H., 2010. Geological offsets and age constraints along the northern Dead Sea fault, Syria. Journal of the Geological Society, 167, s. 1001-1008. https://doi.org/10.1144/0016-76492010-009

Şengör, A. M. C., 1980. Türkiye Neotektoniğinin Esasları (Principles of the Neotectonism of Turkey). Türkiye Jeoloji Kurumu Yayını, 40.

Şengör, A. M. C., 1979. The North Anatolian transform fault; its age, offset and tectonic significance. Journal of the Geological Society of London, 136, $\begin{array}{llll}\text { Part } 3, & \text { S. 269-282. }\end{array}$ https://doi.org/10.1144/gsjgs.136.3.0269

Şengör, A. M. C., Görür, N., ve Şaroğlu, F., 1985. Strike slip faulting and related basin formations in zones of tectonic escape: Turkey as a case study. in StrikeSlip Faulting and Basin Formation 227 - 264, eds. Biddle, K. T., ve Christie-Blick, N., Society of Economic Paleontologists and Mineralogists, Tulsa, Oklahoma, Special Publication No. 37. https://doi.org/10.2110/pec.85.37.0211

Şengör, A. M. C., Grall, C., İmren, C., Le Pichon, X., Görür, N., Henry, P., Karabulut, H., ve Siyako, M., 2014. The geometry of the North Anatolian transform fault in the Sea of Marmara and its temporal evolution: implications for the development of intracontinental transform faults. Canadian Journal of Earth Sciences, 51: 3, s. 222242. https://doi.org/10.1139/cjes-2013-0160

Şengör, A. M. C., Tüysüz, O., İmren, C., Sakınç, M., Eyidoğan, H., Görür, N., Le Pichon, X., ve Rangin, C., 2005. The North Anatolian Fault: A New Look. Annual Review of Earth and Planetary Sciences, 33: 1, $\quad$ s. 37-112. https://doi.org/10.1146/annurev.earth.32.101802.120 415

Şengör, A. M. C., ve Yılmaz, Y., 1981. Tethyan evolution of Turkey: A plate tectonic approach. Tectonophysics, 75: 3-4, s. 181-190, 193-199, 203 241. https://doi.org/10.1016/0040-1951(81)90275-4

Shaw, B., ve Jackson, J., 2010. Earthquake mechanisms and active tectonics of the Hellenic subduction zone. Geophysical Journal International, 181: 2, s. 966984. https://doi.org/10.1111/j.1365246X.2010.04551.X

Tarhan, N., 2008a. 1/100.000 ölçekli Türkiye Jeoloji Hatitaları Serisi, Erzincan J42 paftası, No: 88, Maden Tetkik ve Arama Genel Müdürlüğü Ankara.
Tarhan, N., 2008b. 1/100.000 ölçekli Türkiye Jeoloji Hatitaları Serisi, Erzincan J43 paftası, No: 89, Maden Tetkik ve Arama Genel Müdürlüğü Ankara.

TS 266, 2005. Sular, İnsani Tüketim Amaçlı Sular (Water intended for human consumption), Türk Standartları Enstitüsü, Ankara.

WHO, 2011. Guidelines for drinking water quality. World Health Organization, Fourth Edition, Printed in Malta by Gutenberg, 564s. 